AÜIFD Cilt XLIV (2003) Sayı I s. 83-110

\title{
Kadınların Hadis İlmine Katkıları
}

\section{Mehmet EREN}

Yrd. Doç. Dr., Selçuk Üniversitesi Ilâhiyat Fakültesi

Abstract: Constributions of The Women To 'Ilm Al-Hadith. Ail the muslims, men and women, have contributed much to the formation of the Islamic culture and civilisation. From the time of the companions onwards, the women played important role in preserving and spreading the sayings of the Prophet and also transferring them to the next generations alongside with the men. Between 5th and 10th century A.H., the women showed great interest in the hadith. At this period, the women schoolars of the hadith have performed eminent duties especially by narrating the books on hadith, teaching and instructing the ilm al-hadith. However, they did not write books very much. There are only mujams and mashyakhas in question which were compiled by their students including their narrations and teachers.

Key Words: The women scholars of the hadith, narrating the books on hadith, teaching hadith.

Giriş

İslam kültür ve medeniyetinin oluşumunda, kadın-erkek bütün Müslümanların emeği vardır. Peygamberin (a.s.) İslâm'ı tebliğe başlamasından itibaren Müslüman olan hanımlar, daima erkeklerle birlikte dini yaşama ve yayma faaliyetinin içinde olmuşlardır. Habeşistan'a hicret edenler arasında ve Akabe biatlerinde kadınların da bulunması bunu gösterir. Yine birçok 
kadın sahâbî, dinleri uğruna Medine'ye hicret etmişlerdir. Ayrıca, bilindiği gibi Rasûlüllah (a.s.) kadın Miislümanlardan özel bir biat almıştır.'

Bunlar, İslâmiyet'in ilk yıllarından itibaren Müslüman kadınların dinlerine yaptıkları hizmetlerinin, erkeklerle birlikte bu uğurda çalışıp gayret gösterdiklerinin en açık delilleridir. İbn Sa'd (230/844), Tabakât' 'nda sahâbî hanımların biyografilerinin çığunda; "Müslüman oldu, hicret etti, Rasûlullah (a.s.)'a biat etti, ... savaşına katıldı" şeklinde bilgi vermektedir. ${ }^{2}$

Bu yazıda, "kadınların Fïadis ilmine katkıları" ${ }^{3}$ konusunu, iki ana başlık altında işlemeye çalışacağız. İlk bölümde, "rivayet asırları" olarak adlandırılabilecek hicrî dördüncü asra kadar olan zaman dilimindeki katkılarından; ikinci bölümde de sonraki asırlardaki hizmetlerinden bahsedeceğiz. İki bölümdeki bilgileri de, daha çok "Rical Edebiyatı" adı verilen biyografi kaynaklarından toplayarak değerlendirmeye çalışacağız.

\section{Rivâyet Asırlarında Kadınların Hadis İlmine Katkıları}

\section{A. Sahâbe Dönemi}

Erkek sahâbîler, Peygamber'den (a.s.) duyduklarını-gördüklerini naklettikleri gibi, kadın sahâbîlêr de bu görevi îfâ etmişlerdir. Hattâ onlar, "erkeklere göre kendisini fazla dinleme imkânı bulamadıklarını belirterek, Peygamber'den kendileri için özel bir gün tahsis etmesini" istemişlerdir. Bir hanım, Rasûlullâh'a gelerek, onun konuşmalarından hep erkeklerin istifade ettiğini hatırlatmış ve kadınlar için de bir gün tahsis edilmesini istemiştir. Bu

' Âyet için bkz. Mümtehine 60/1':. Hadis ve İslâm Tarihi kaynaklarındaki rivâyctlerden, $\mathrm{Hz}$.

Peygamber'in, Mekke ve Midine'de, muhtelif zamanlarda, kadınlardan biat aldığı anlaşılmaktadır. Ona biat eden hanım sahâbîlerle ilgili rivâyctler için bkz. İbn Sa'd, Ebû Abdillah Muhammed b. Sa'd, K. et-Tabakâti'l-Kebîr Beyrut, 1388/1968 VIII, 5-13, 236237.

2 Ensâr'lı Ümmü 'Umâre ile Ümmü 'Atıyyc. hemen-hemen bütün savaşlara katılan hanımlardandır. Ümmü 'Atıyyz: "Rasûlullah ile yedi savaşa katıldım. Onların yemeklerini yapar ve eşyalarını bcklerdim. Yaralıları tedavi eder, hastalara bakardım." demiştir. (İbn Sa'd, VIII, 455. Ủmmü 'Umáre için bkz. VIII. 412-416) Sahâbeden bir grup ve Basra'lı tâbiîn âlimleri, ölü yıkama işini Ümmü 'Atıyye'den öğrenmişlerdir. (İbn Hacer cl'Askalânî. Ahmed b. Ali, Tehzibü't-Tehzîb -Beyrut, 1417/1996, VI, 562)

${ }^{3}$ Kadınların Hadis ilmine hizmetieri konusunda yapılan müstakil iki çalışmaya işaret etmek istiyoruz: Meşhûr b. Hasen Â.l Selmân'ın 'Inâyetü'n-Nisâ bi'l-Hadîsi'n-Nebevî adılı kitabı. 1414/1994'te Beyrut'ta neşrıdilmiştir. Nusrettin Bolelli'nin hazırladı̆̆ doktora tezi, Kadınların Hadis Ilmindeki Yeri 'M.ÜJ. Illâhiyât Fakültesi Vakfı Yay., İstanbul, 1998' adıyla yayımlanmışır. Hiırî II-V asırlăda yaşamış olan hanım muhaddislerin biyografilerinin işlendiği bu tezin otuz. sayfalık son bölümünde, "Hanım Muhaddislerin Hadis Öğrenme ve Ögretme Müesseseleri ve Metodları" başlığı altında, kadınların Hadis ilmine katkılan üzerinde durulduğunu söyleyebiliriz. 
teklifi kabul eden Peygamberimiz, belirli bir yerde ve günde toplanmalarını isteyerek, Allâh'ın kendisine öğrettiği hususları onlara da öğretmiştir. ${ }^{4}$

Ahmed b. Hanbel (241/855), Rasûlullah'tan rivâyeti olan 101 hanım sahâbînin isimlerini sayar.' İbn 'Asâkir'in (571/1175), Ahmed b. Hanbel'in Müsned'i için hazırladığı fihriste göre; Müsned'de kimliği belirtilen 92 ve müphem olarak 33 olmak üzere toplam 125 kadın sahâbî vardır. ${ }^{6}$ Bakî b. Mahled'in (276/889) Müsned'ine göre ise, hadis nakleden hanım sahâbî sayısı 122'idir. Bunlardan 28'i on ve daha fazla sayıda, 22'si dört-on arasında, geri kalanlardan bir kısmı iki-üç, büyük bölümü ise tek hadis nakletmiştir. ${ }^{7}$

Peygamberimizin eşlerinden Âişe (57/677), Hafsa (50/670), Ümmü Habîbe (44/664), Meymûne (49/669) ve Ümmü Seleme'nin (61/681) hadislerin yayılmasında büyük hizmetleri olmuştur. Bakî'nin Müsned'indeki sayllara göre; Âişe'nin 2210, Ưmmü Seleme'nin 378, Meymûne'nin 76, Ümmü Habîbe'nin 65, Hafsa'nın 60 rivâyeti vardır. ${ }^{8}$ Âişe, Hafsa ve Ümmü Seleme'ye nispet edilen Mushaf'ların olması, ${ }^{9}$ bu üç annemizin Kur'ân ve Sünnet bilgilerinin çokluğuna ve ilimle meşgul olduklarına en güzel delildir. ${ }^{10}$ Ensâr'lı Ümmü Varaka bint Abdillah b. el-Hâris'in de, Kur'ân'ı cem ettiği bildirilmiştir."

"Buhârî, "İlim", 36; Müslim, "Birr", 152; Tirmizî, "Birr", 13; Ahmed b. Hanbel, III, 34, 72; IV, 154; VI, 27, 29.

${ }^{5}$ Ahmed b. Hanbel, el-Câni' fill-'llel ve Ma'rifetü'r-Ricâl 'Beyrut, 1410/1990' II, 244-246.

'İbn 'Asâkir, Ali b. el-Hasen, Ternibü Esmâi's-Sahâbe 'Beyrut 1409/1989' s. 33-34.

${ }^{7}$ Hanım sahâbîlerin rivâyet cttikleri hadis sayıları için, Ekrem Ziyâ el-'Umeñ'nin hazırladı̆̆ı Bakî b. Mahled el-Kurtubî ve Mukaddimetü Müsnedihî 'Beyrut, 1404/1984' adlı kitaptan isimlerinin geçtiği yerlere bakılabilir. İbn Sa'd'ın, sahâbe ve tâbiînden kadın biyografilerini ihtiva eden Tabakât'ının son cildinde, Peygamber (a.s.)'den tek rivâyeti olanların bu rivâyetlerini zikretmcye özen gösterdiği anlaşılmaktadır.

${ }^{8}$ Ondan fazla sayıda hadis rivâyet etmiş olan diğer hanım sahâbîler ve rivâyet sayıları şöyledir: Esmâ bint Yezîd 81, Esmâ bint 'Umeys 60, Esmâ bint Ebî Bekr 58, Ümmü Hâni bint Ebî Tâlib 46. Ümmü 'Atıyye (Nesîbe bint el-Hâris) 40, Fâtıma bint Kays 34, Ümmü'lFadl Lübâbe bint el-Hâris 30, Ümmü Kays bint Mihsan 24, Rubeyyi ' bint Muavviz. 21, Hz. Fâtıma 18, Havle bint Hakîm 15, Ummü Süleym 14, cş-Şifâ bint Abdillah 12, Sübey'a elEslemiyye 12, Zeyneb bint Cahş 11, Dubâ'a bint ez-Zübeyr 11 ve Büsrc bint Safvân 11 . bkz. Bakî b. Mahled el-Kurtubî ve Mukaddimetü Müsnedihî.

Tâbiînden sadece bir kişinin rivâyet naklettiği hanım sahâbîler şunlardır: Ümmü'l- 'Alâ' (bint el-Hâris) cl-Ensâriyye, Evs b. es-Sâmit'in hanımı Huveyle (Havle) bint Sa'lcbe, Benî Leys kabilesinden Sumeyte adlı kadın, Ümeyme bint Rukayka, Hubeyb b. Abdirrahmân'ın halası Üneyse, Ümmü Cemîl bint el-Mücellel el-'Âmiriyyc ve Abdullah b. Ebî Hıdred'in hanımı Fükayra (Müleyke de denir) el-Hilâliyye. 'Müslim, el-Münferidât ve'l-Vuhdân' Beyrut, 1408/1988- s. 88-94.

9 Abdullah b. Ebî Dâvûd, Kitâbü'l-Mesâhıf 'Beyrut, 1405/1985' s. 94-98.

10 Tâbiîn âlimlerinden erkek-kadın birçok kişi, bilhassa Âişe ve Ưmmü Seleme'den olmak üzere, ümmühâtü'l-mü'minîn'den çok rivâyet nakletmişlerdir. Mesrûk ve cl-Esved b. 
Bazı hanım sahâbîler, şiiâhî rivâyetin yanında, hadisleri yazmak veya yazdırmak suretiyle de bu iline hizmet etmişlerdir. Birçok kişi, problemlerinin halli veya bir konuda bilgi edinmek için $\mathrm{Hz}$. Âişe'ye mektup yazmış, o da bunlara cevap göndesmiştir. ${ }^{12}$ Atâ b. Yesâr, Meymûne'ye mesh konusunda bir hadisi sorarak, cevabını defterine kaydetmiştir. ${ }^{13}$ Ebû Seleme,

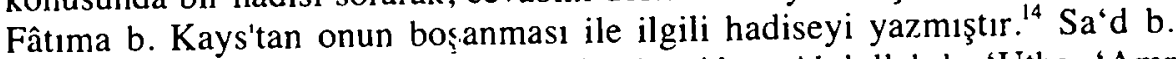
Havle'nin hanımı olan Sübey'a el-Eslemiyye'den; Abdullah b. 'Utbe, 'Amr b. 'Utbe, Ömer b. Abdillah ve Mesrûk hadis yazmışlardır. "' Esmâ bint 'Umeys'in yanında, Rasûlulliah'ın bazı hadislerini ihtiva eden bir sahîfe'nin bulunduğu bildirilmiştir. ${ }^{16}$

Sahâbî hanımlar, Rasûlullah'ın hadislerini rivâyet etmenin ve yazdırmanın yanında, sorulan soruları cevaplamışlar, yanlış bilinen ve aktarılan hususları düzeltmişlerdir. Bu konuda $\mathrm{Hz}$. Âişe'nin katkıları, müstakil bir kitap hacminde toplanmış bılunmaktadır. ${ }^{17} \mathrm{O}$, bir grup sahâbinin rivâyetlerinde yaptıkları hataları göstermiştir. Onun ilminin çokluğunu bilen sahâbe, şüphelendikleri rivâyetleri kendisine sormuşlar, uzakta iseler mektup yazarak sorularını göndermiş ${ }^{1}$ er, ${ }^{18}$ verdiği cevapları kabul etmişlerdir.

Âişe vâlidemiz; Kur'ân, hadis, fıkıh, ferâiz, helal-haram gibi dînî konularda ve tıp, şiir-edebiyat, Arap tarihi ve ensâbı bilgilerinde, sahâbenin en büyük âlimi olarak kabul edilir. ${ }^{19}$ Öyle ki, büyük sahâbîler, çözemedikleri meseleleri gelip ona sormakiadırlar. Nitekim Ebû Mûsâ el-Eşan̂ (r.a.)'nin şu sözü bunu teyit eder: "Muhammed'in ashâbı olan bizler, her ne zaman çözmekte zorlandığımız bir meseleyi Âişe'ye sormuşsak, mutlaka o mesele

Yezid'in, Hz. Âişe'den yazdıkları nüshaları vardır. Es'ad Sâlim Tcym. 'llmu Tabakâti'lMuhaddisin -Riyâd, 1415/1994-s.113,115.

"İbn Sa'd, VIII, 457. Ümmü Varaka için bkz. İbn Hacer, Tehzîb VI, 578.

${ }^{12}$ Bazı misaller için bkz. A'zamî. Muhammed Mustafa, Dirâsât fi'l-Hadîsi'n-Nebevî 'Beyrut, 1413/1992' I, 114.

${ }^{13}$ Müsned, VI, 333.

${ }^{14}$ Müslim, "Talâk", 39; Müsned, VI, 413.

${ }^{15}$ A'zamî, I, 109-110.

${ }^{16}$ A'zamî. I, 100. Ömer b. Abdilazîz'in kızı Âmine hanımın, Hz. Peygamber'in hizmetçisi Meymûne bint Sa'd'den naklıttiği hadislerin, muhaddisler tarafından bir nüsha halinde rivâyet edildiği anlaşılmaktadır. İbn 'Asâkir, Târîhu Dımaşk, Beyrut, 1415 /1995, LXIX, 41-42.

${ }^{17}$ Bedrüđdîn ez-Zerkeşî́nin (794/1392) el-icâbe adlı kitabı, Bünyamin Erul tarafından -ilâve incelemelerle- Hz. Âişe'nin Sahâbeve' Yönelttiģi Eleştiriler Kitâbiyât, Ankara-2000, adıyla dilimize kazandırılmıştır.

${ }^{18}$ Buhân, el-Edebüll-Müfred Beyrut, 1410/1990, s. 326.

${ }^{19}$ Ilgili rivâyetler için bkz.. el-Hâkim en-Neysâbûn, Muhammed b. Abdillah, el-Müstedrek, Beyrut ts., IV, 11. 
hakkında bir bilgisinin olduğunu görmüşüzdür." ${ }^{20}$ Tâbiîn imamlarından Mesrûk da şöyle demektedir: "Muhammed'in yaşlı/büyük ashabını, Âişe'ye ferâiz meselelerini sorarlarken gördüm.,"21

Böylece, başta müminlerin anneleri olan Peygamber eşleri olmak üzere, sahâbî hanımlar, hadisleri başkalarına şifâhî veya yazılı olarak rivâyet etmek ve hadis rivâyetinde yapılan hataları düzeltmek suretiyle, Rasûlullah'ın sünnetinin sonraki nesillere intikalinde, üzerlerine düşen görevi yerine getirmeye çalışmışlardır. Onlar, Peygamber'den hadis naklinin yanında, Kur'ân tefsiri ve fıkıh konularıyla ilgili bilgilerini de, talebelerine ögretmekten geri kalmamışlardır.

\section{B. Tâbiîn, Tebe-i Tâbiîn ve Sonraki Nesiller}

Kadınların hadis eğitim-öğretimindeki katkıları, sahâbe tabakasından sonra da devam etmiştir. Tâbiîn ve sonraki nesillerden, hadis rivâyeti ile meşgul olan bir çok meşhur hanım vardır. Bu husus, sayıları erkek râvîlerin sayısı kadar çok olmasa da, her nesilde Hadis ilmine hizmet etmiş kadınların bulunduğunu göstermesi açısından önemlidir.

Müslim (261/874), Tabakât'ında tâbiînden olan hanım muhaddisleri memleketlerine göre gruplara ayırarak; Medine'li 69, Mekke'li 8, Kûfe'li 11, Basra'lı 4 ve Şam'lı 3 olmak üzere 95 kişi olarak saymıştır. ${ }^{22}$ Tâbiîn dönemindeki kadın muhaddislerin büyük çoğunluğu Medine'de ikâmet etmiştir. Bu şehir, sahâbe ve tâbiîn dönemlerinde Hadis ilminin merkezidir. İbn Hıbbân (354/965), Kitâbü's-Sikât'ında -4. ve 5. ciitler- her harfin sonunda, ismi o harf ile başlayan tâbiînden 66 kadın hakkında kısa bilgi verir.

Tâbiîn dönemi hanım muhaddislerini hicrî 1. ve 2. asırda yaşamış olanlar şeklinde ikiye ayıran Nusrettin Bolelli ise, 246'sı birinci ve 39'u ikinci asırda olmak üzere, bize toplam 285 hanımın biyografisini sunmaktadır. Tâbiîn ve sonraki dönemlerdeki kadın muhaddis sayıları hakkında dikkat çeken husus, ilk asırdan sonra hanım muhaddis sayısındaki büyük düşüştür. Bolelli'nin tespitine göre; 1 . asırda 246, 2. asırda 39, 3.

${ }^{30}$ Zehebî, Muhammed b. Ahmed, Siyeru A 'lâmi'n-Nübelâ 'Beyrut, 1402/1982' II, 179; Íbn Hacer, Tehzîb, VI, 551.

${ }^{21}$ İbn Sa'd, VIII, 66; Zehebî, Nübelâ, II, 181. Diğer fakîh hanım sahâbiler arasında şu kişiler sayılmaktadır: Hz. Fâtıma, Hafsa bint Ömer, Ümmü Seleme, Ümmü Habîbe, Esmâ bint Ebî Bekr, Ümmü'l-Fadl bint el-Hâris ve Ümmü Hâni' bint Ebî Tâlib. Ebû İshâk eş-Şîrâzî. İbrâhîm b. Ali, Tabakâtü'l-Fukahâ, -Beyrut, 1401/1981-s. 52.

${ }^{22}$ Meşhûr b. Hasen, 'Inâyetü'n-Nisâ bi'l-Hadisi'n-Nebevî 'Beyrut, 1414/1994' s. 52. İbn Sa'd, Tabakât'ın sonunda, "Rasûlullah'tan rivâyetleri olmayıp, hanımlarından ve diğer sahâbîlerden rivâyet eden kadınlar"ın biyografilerini sunar. (VIII, 461-498) Sahâbe kızlanı ve torunları olan bu bölümdeki kadınlardan bir çoğunun, $\mathrm{Hz}$. Âişe'den rivâyet nakletmiş olması dikkat çekmektedir. 
asırda 10,4. asırda 17 hanım muhaddis vardır. Beşinci asra gelindiğinde sayı tekrar yükselerek 45 'e ulaşmıştır. ${ }^{2.3}$

Kanaatimizce bunun en önemli sebebi; sahâbe ve büyük tâbiîler döneminde şifâhî rivâyetin yaygıın olmasından dolayı, erkek olsun kadın olsun Müslümanların bildiklerini aktarmaya önem vermiş olmalarıdır. Sonraki dönemlerde, rivâyet edilen hadisler büyük ölçüde kitaplara geçirildiği için, şifâhî rivây'etin önemi azalmıştır. Beşinci asırda sayının tekrar yükselmeye başlaması, bu asırda hadis kitaplarının ve cüzlerinin rivâyet edilmesinin önem kazanmış olmasından dolayıdır. Zira, dördüncü asırdan itibaren, bir çok kadın muhaddisin, rivâyet hakkını elde ettiği hadis kitaplarını ve cüzlerini başkalarına rivâyet ettiği görülmektedir.

Tâbiîn döneminde, ümrnühâtü'l-müminînden ve diğer sahâbîlerden ilim öğrenen ve hadis rivâyet edın meşhur kadın muhaddisler şunlardır: Safiyye bint Şeybe (h. 1. asır), Safịyye bint Ebî Ubeyd (h. 1. asır), Âişe bint Talha (110/728), Mu'âze bint Abdillah (83/702), Ümmü'd-Derdâ es-Suğrâ diye meşhur olan Hüceyme bint Huyey (81/700), Hafsa bint Sirîn (101/719) ve 'Amra bint Abdirrahmân (98/716). ${ }^{24}$

Âişe, Ümmü Habîbe ve Ümmü Seleme annelerimiz ile diğer bazı sahâbîlerden hadis rivâyet eden Safiyye bint Şeybe'den, çok sayıda kişi rivâyet nakletmiştir. ${ }^{25}$ Abdullah b. Ömer'in hanımı Safiyye bint Ebî 'Ubeyd ise, Hz. Âişe, Hafsa ve Ümmü Seleme annelerimiz ile el-Kâsım b. Muhammed b. Ebî Bekr es-Sıddîk'tan rivâyet nakletmiştir. Iclî onun için "Medine'li sika bir tâbiî" demiş, İbn Hibbân da onu Sikât' 'nda zikretmiştir. ${ }^{26}$

'Amra bint Abdirrahmàn, $\mathrm{Hz}$. Âiş̧e'nin terbiyesinde büyümüş, talebesi olarak yetişmiştir. Bu yüzden, onun rivâyetleri konusunda en güvenilir otorite kabul edilir. Âiş̧e'nin rivâyetleri konusunda güvenilen diğer iki kişi, el-Kâsım b. Muhammed b. Ebî Bekr (112/730) ile 'Urve b. ez-Zübeyr (94/712)'dir. Halîfe Ömer b. Abdilazîz, Medine Valisi Ebû Bekr b. Muhammed b. Hazm'e gönderdiği yazılı emirde, 'Amra'nın rivâyet ettiği hadisleri de yazmasını isterniştir. ${ }^{27}$ el-Kâsım $b$. Muhammed, ilim öğrenmeye çok hırslı olan İbn Şihâtı ez-Zührî'ye, Âişe'nin terbiyesinde yetiştiğini belirttiği ilim hazinesi 'Amra'ya gitmesini tavsiye etmiştir. İbn Şihâb, yanına vardığında, ilim bakımından onun bir derya olduğunu görmüștür ${ }^{28}$

Hz. Âişe'nin kardeşi Ümmü Gülsüm'ün kızı olan Âişe bint Talha, teyzesi Âişe'den rivâyet nakleden kadınlardan biridir. Kendisinden de çok

\footnotetext{
${ }^{23}$ Bolelli, Kadınların Hadis Ilmindeki Yeri 'İstanbul, 1998' s. 46-194.

${ }^{24}$ Zehebî, el-Mu'în fí Tabakâti'l-Muhaddisîn 'Kâhire, 1407/1987' s. 49.

${ }^{25}$ Nevevî, Yahyâ b. Şercf, Tehzíbü'l-Esmâ ve'l-Lüğât 'Bcyrut, 1416/1996' II, 614; Ibn Hacer,

Tehzîb VI, 548. Ayrıca bkz. Mizzî, Yûsuf b. Abdirrahmân, Tehzîbü'l-Kemâl 'Beyrut, 14031405' XXXV, 211

${ }^{26}$ İbn Hacer, Tehzîb, VI, 548. Aynca bkz. Mizzî, XXXV, 212.

${ }^{n}$ İbn Sa'd, II, 387; VIII, 480; M zzî, XXXIII, 140; İbn Hacer, Tehzîb, VI, 552-553.

${ }^{28}$ Zehebî, Nübelâ, IV, 508; Mizzì. XXXV, 241.
} 
sayıda kişi hadis rivâyet etmiştir. Yahyâ b. Ma'în, onun için en yüksek güvenilirlik derecesi kabul edilen "sika, huccet" ifadesini kullanmış, "Iclî de onu "Medîne'li sika bir tâbî̀" şeklinde tavsif etmiştir. ${ }^{29}$

Henüz on iki yaşında iken Kur'ân'ı okuyan ve fakih kimliği ile meşhur olan Hafsa bint Sîrîn; Ümmü Atıyye el-Ensâriyye, Enes b. Mâlik gibi sahâbîler ile tâbiîn âlimlerinden rivâyet nakletmiş, kendisinden de birçok kişi ilim öğrenmiştir. Yahyâ b. Ma'în, onun için "sika, huccet" değerlendirmesinde bulunmuş, "Iclî de "Basra'l sika bir kişi" demiştir." Âlim ve âbid kimliği ile meşhur Mu'âze bint Abdillah; Hz. Âişe, Ali ve başkalarından hadis rivâyet etmiş, kendisinden de çok sayıda meşhur kişi rivâyet almıştır. Yahyâ b. Ma î̂n, onun hakkında yine "sika, huccet" değerlendirmesinde bulunmuştur. ${ }^{31}$

Geniş bir ilme ve üstün bir zekâya sahip olduğu bildirilen, fakih/âlim ve âbid kimliği ile tanınan Ümmü'd-Derdâ es-Suğrâ, özellikle kocası Ebü'dDerdâ başta olmak üzere, birçok sahâbîden çok sayıda hadis ve bilgi nakletmiştir. Bu yüzden o, Ebû Ahmed el-'Assâl tarafından "rivâyetleri ve görüşleri toplanacak kişiler" arasında sayılır. O, daha küçük yaşlarından itibaren kurrâ'nın ders halkalarına katılarak Kur'ân'ı öğrenmiş ve onu Ebü'dDerdâ'ya arz etmiştir. ${ }^{32}$

Ümmü Seleme'nin kızı Zeyneb bint Ebî Seleme (73/692); annesi Ümmü Seleme ile Hz. Âişe, Zeyneb bint Cahş ve Ümmü Habîbe'den hadis rivâyet etmiştir. O, Medine'li hanımlar arasında fakîh kimliği ile dikkat çekmektedir. ${ }^{33}$ Peygamber'in hanımlarından altı tanesini gördüğ̈̈u söylenen Sa'd b. Ebî Vakkâs'ın kızı Âişe (117/735), babasından ve Ümmü Zerr'den hadis rivâyet etmiştir. "Iclî, onu "Medine'li sika bir tâbiî" şeklinde tanıtmıştır. ${ }^{34} \mathrm{~Hz}$. Ẩişe'nin hizmetçisi olan Ümmü 'Alkame Mercâne hakkında 'Iclî, "Medîne'li sika bir tâbiî" demiştir. Ümmü 'Alkame, Âişe ile Muâviye'den; kendisinden de oğlu 'Alkame ile Bükeyr b. el-Eşecc hadis

\footnotetext{
${ }^{29}$ Biyografisi için bkz. Mizzî, XXXV, 237; Zehebî, Nübelâ, IV, 369.

${ }^{30}$ Biyografisi için bkz. Mizzî, XXXV, 151; Zehebî, Nübelâ, IV, 507.

${ }^{31}$ Biyografisi için bkz. Mizzî, XXXV, 308; Zchebî, Nübelâ, IV, 508.

${ }^{32}$ Biyografisi için bkz. İbn 'Asâkir, Târîhu Dımaşk LXX, 146-160; Mizzî, XXXV, 352; Zehebî, Nübelâ, IV. 277; Tezkiretü'l-Huffâz 'Kâhire, ts.' 1, 53. 'Avn b. Abdillah şöyle anlatır: "Ümmü'd-Derdâ'nın meclisinde bulunuyorduk. Ona, 'seni usandırdık mı?' dedik. Bunun üzerine bize şöyle dedi: "Her işte ibâdet yapmış olmayı istemişimdir. Kendim için, 'âlimlerle birlikte olmak ve onlarla müzâkerc etmckten daha şifalı (faydalı) bir şey göremedim." İbn 'Asâkir, Târîhu Dımaşk' LXX, 156-157; Nevevî, II. 623; Mizzî, XXXV, 355.

${ }^{33}$ İbn Hacer, Tehzîb, VI, 543.

${ }^{34}$ Ibn Hacer, Tehzîb. VI, 551. "Âişe bint Sa'd" adında Basra'lı başka bir hanım daha vardır. O, el-Hasen el-Basrî ile Hafsa bint Sîrîn'den rivâyet etmiş, kendisinden de zayı̊ ve metrûk râvîlerden biri olan Abdurrahmân b. Amr b. Cebele el-Basrî haber nakletmiştir. 'Mizzî, XXXV, 237'
} 
rivâyet etmiştir. ${ }^{35}$ İmam Mâlik, oğlu 'Alkame vasıtasıyla, ondan bazı hadisler nakleder. ${ }^{36}$

Bunlar, tâbiîn döneminin meşhur hanım muhaddisleridir. Görüldüğü gibi, onlar hadis rivâyetinde sika/güvenilir râvîler kabul edilmektedirler. Sahâbe neslinden devraldıkları mirası, sonraki nesle aktarmada üzerlerine düşen görevi yerine getirmıeye çalışmışlardır. Hadis imamlarının onlardan nakletmiş oldukları rivâyetler, hadis kaynaklarımızda yer almaktadır. ${ }^{37}$

\section{Hadis İmamlarınırı Kadın Râvílerden Rivâyeti}

İlk asırlardan itibaren, muhaddisler kadınlardan da rivâyet almışlardır. Ancak bir muhaddisin çok sayıda kadından rivâyet alıp-almaması, kanaatimizce kişisel tercih ile alakalı olan bir husustur. Zira, bazı muhaddislerin rivâyet aldığı hocaları arasında birçok hanım varken, bazılarının ancak bir-iki tane kadın hocasının olduğu görülmektedir.

İbn Şihâb (124/742), 'Amra bint Abdirrahmân'dan çok hadis rivâyet etmiştir. O, ayrıca başka kimsenin kendilerinden hadis nakletmediği şu üç hanımdan da rivâyet eder: Hind bint el-Hâris el-Firâsiyye, Fâtıma elHuzâ'iyye ve Ümmü Abdillah ed-Devsiyye. ${ }^{38}$ Íbn Cüreyc (150/767), başka kimsenin hadis almadığl Leylâ bint Saîd, Halîme bint Hakîm (veya Hukeyme bint Ümeyme bint Rukayka) ve Abdurrahmân b. Hayyân'ın hizmetçisi Bünâne'den rivíiyet almıştır. ${ }^{39}$ Mâlik (179/795) ise, Âişe bint Sa'd b. Ebî Vakkâs (117/735)'tan başka hiçbir hanımdan rivâyet nakletmemiştir. ${ }^{40}$

Çok sayıda hanımdar rivâyet yazan ve nakleden muhaddisler de vardır. Örneğin, sekiz yüz hocadan hadis yazdığı bildirilen Müslim b. Ibrâhîm elFerâhîdî (222/837)'nin, yetmiş kadından rivâyet ettiği/hadis yazdığı belirtilmektedir. Ğıbta bint 'Amr da onun hadis rivâyet ettiği hanımlardan

${ }^{35}$ İbn Hacer, Tehzîb, VI, 573.

${ }^{36}$ Muvatta', "Tahâret", 97; "Nidiì"(Salât), 67; "Cenâiz", 55; "Hacc", 48, 93; "Libâs", 6.

${ }^{37}$ Dokuz ana hadis kitabındaki rivâyetleri için, Concordance'in son cildinde isimlerinin geçtiği yerlere bakılabilir.

${ }^{38}$ Müslim, Münferidât, s. 123-124. Mizzi, XXVI, 426-427. (Sadece 'Amra ile Hind zikredilir)

${ }^{39}$ Müslim, Münferidât, s. 224-225. Mizzî, XVIII, 344. (Bünâne ile Hukeyme zikredilir)

${ }^{40}$ Mizzî, XXVII, 106; İ̉n Hacer, Tehzỉi, VI, 551. Ebû Ya'lâ el-Halîlî (446/1054), Mâlik'in, kitaplarında başka hiç bir kadın hocadan rivâyet etmediğini söylemektedir. el-İşấd fi Ma'rifeti 'Ulemâi't-Bilâd 'Beyrut, 1414/1993' s. 29. Medîne imamının, şehrindeki çok sayıda kadın muhaddisten rloğrudan hadis rivâyet etmemesi dikkat çekicidir. Muvatta'da, "Âişe bint Sa'd b. Ebî Vakkâs" deģil, "Âişe bint Talha b. Ubeydillah" ismi geçmektedir. ("Sıyâm", 16) Muvatıa' ricâ'i için kitap yazan mücllifler de, "Âiş̧e bint Sa'd b. Ebi Vakkâs" adını zikretmezler. (Meselâ bkz. Süyûtî, Is'âfü'l-Mübatıa' -Tenvîrü'l-Havâlik'in sonunda, Bcyrut ts, s. 48-50) Mâlik, aslında Âişe bint Sa'd b. Ebî Vakkâs ile görüşmüş ve ona bazı rivâyetleri sormuştur. Anciłk zayıf bir râvî olmasından dolayı, kendisinden herhangi bir rivâyet almamıştır. bkz. el-Cânii' fi'l-Cerh ve't-Ta'dîl 'Derleyenler: İbrâhîm Muhammed en-Nûni ve diğ., Beyrut 1412/1992’ III, 474. 
biridir. ${ }^{41}$ Ahmed b. Hanbel, Ưmmü Amr bint Ebi'l-Ğusn'dan rivâyet etmiştir. Yahyâ b. Ma'în önceden bu hanımdan semâ etmiş ise de, sonra "leyset bi şey" diyerek, onun zayıf olduğunu belirtmiştir. Ahmed b. Hanbel'in oğlu Abdullah, Ümmü Muhammed Hatîce adlı hanımdan rivâyet etmiştir. O, bu kadının, babası Ahmed b. Hanbel'in derslerine gelerek ondan hadis dinlediğini ve dinlediği hadisleri başkalarına rivâyet ettiğini bildirmektedir. ${ }^{42}$

\section{Kadın Râvîlerin Cerh-Ta'dîl Durumu}

Kadın râvîlerle ilgili önemli bir husus, onların hadis rivâyetinde genel olarak güvenilir olmalarıdır. Tedlîs, ihtilât ve telkîn gibi râvînin rivâyetini zayıflatan kusurlarla vasıflanan kadın sayısı azdır. Zehebî, zayıf râvîler için yazdığı Mîzân'ın sonunda, "tek râvîsi olduğu için meçhul sayılan kadın râvîler"in biyografilerine başlarken, "kadınlardan yalancılıkla itham edilen ve hadisleri terk edilen kimse bilmiyorum"^3 demiştir. Ancak, sayıları az olmakla birlikte, kadın râvîler arasında, "kim olduğu bilinmeyen", "hadis rivâyetinde zayıf görülen" veya "cerh-tadîl durumu ihtilâflı olan"lar vardır. Bu konuda, misal olmak üzere şu kişileri zikredebiliriz:

'Iclî'nin "sika bir tâbiî" şeklinde tavsif ettiği Kûfe'li Cesre bint Dicâce el-'Âmiriyye'nin, Buhârî'ye göre bazı garib rivâyetleri vardır. İbn Hazm, onun rivâyetlerinin bâtıl olduğunu iddia etmiştir. ${ }^{44}$ Bezzàr'a göre, ondan Kudâme b. Abdillah'tan başka kimse rivâyet etmemiştir. Dârekutnî ise, kendisinden metrûk kişilerin naklettikleri hariç, onun rivâyetlerinin i`tibâr için kullanılabileceğini bildirmektedir. ${ }^{45}$

Dârekutnî, "Zeynep es-Sehmiyye" denilen Zeyneb bint Muhammed b. Abdillah b. Amr b. el-Âs'ın, bilinmeyen bir kişi (mechû̀:e) olduğunu ve

${ }^{41}$ Mizzî, XXVII, 489, 491; Hazrecî, Ahmed b. Abdillah, Hulâsatü Tezhỉbi Tehzîbi'l-Kemâl. Beyrut, 1411, s. 374 .

${ }^{42}$ el-Hatîbü'l-Bağdâdî, Târîhu Băgdâd 'Beyrut, ts.' XIV, 432-3, 435; İbn 'Asâkir, Târîhu Dımaşk, LXX. 157. Ahmed b. Hanbel, Yahyâ b. Ma'în, Ali b. el-Medînî, Buhârî ve Müslim gibi tasnif döneminin önemli muhaddislerinin, rivâyet aldıkları kadın hocalannın adları zikredilmez. (Mizzî, I, 440; XXXI, 546; XXI, 7; XXIV, 434; XXVII, 504) Tabarânî (360/971), dört tane hanım hocasından bazı rivâyetler nakletmektecir. 'el-Mu'cemü'sSağîr' Beyrut, 1403- II, 151-153

${ }^{43}$ Zehebî, Mìzânu'l-I'tidâl fi Nakdi'r-Ricâl 'Beyrut, ts.' IV, 604-616. Burada, "kimliği tam olarak bilinmeyen", "künyeleriyle tanınan" ve "isimleri belli olmayan" başlıklan alında, şahısları ve cerh-tadil durumları bilinmeyen 120 civarında hanım zikredilmiştir. Haklarında, mechûle, lâ tu'raf, lâ yu'rafü hâlühâ gibi tenkit ifadeleri kullanılır. Onlardan sadece bir kişi hadis rivâyet ettiği için, kim oldukları bilinememekte, bu yüz.den zayıf sayılmaktadırlar.

${ }^{44}$ Ibn Hacer, Tehzîb, VI, 534. Onun nebiz hakkında Hz. Âişe'den rivâyet ettiği hadis için bkz. Nesâî, "Eşribe", 48. Tirmizî ve İbn Mâce, bu hadisi farklı senet ve muhteva ile nakletmişlerdir. Tirmiẑ̂, "Eşribe", 7; İbn Mâce, "Eşribe", 12.

${ }^{45}$ el-Câmi' fi'l-Cerh ve't-Ta'dîl, IIl, 470 . 
rivâyetinin delil olarak kullanılamayacağını söylemiş, İbn Abdilberr de benzer açılklamada bulunmuştur. ${ }^{46}$

Hz. Âişe'den bir hadis rivâyet etmiş olan Müseyke el-Mekkiyye hakkında İbn Huzeyme: "Oģ,lu Y'ûsuf b. Mâhek'ten başka ondan rivâyet eden kimse hatırlamıyorum ve hakkında ne adâlet, ne de cerh hükmü biliyorum" ${ }^{47}$ demiştir.

Îmam Mâlik, Âişe bint Sa'd b. Ebî Vakkâs ile görüşüp kendisine bazı hadisleri sormuş, ancak hadis rivâyeti konusunda zayıf bir râvî olduğu için, ondan herhangi bir rivâyet almaya gönlü razı olmamıştır. ${ }^{48}$ Halbuki 'Iclî onu "Medîne'li sika bir tâbiî" şeklinde tanıtmış, İbn Hıbbân da Sikât'ında zikretmiştir. ${ }^{49}$

Yukarıda dikkat çektigimiz gibi, hicrî ikinci asırdan itibaren Hadis ilmiyle iştigal eden kadınların sayısında önemli bir düşü̧̧ görülmektedir. Sahâbe ve tâbiîn nesillerinden bir çok hanım, hadis rivâyetiyle meşgul olduğu halde, sonraki asırlarda -herhalde rivâyetler kitaplara geçtiği için olsa gerek- kadınların hadis rivâyetine rağbeti azalmıştır. Ibn Hacer'in elKütübü's-Sitte'de rivâyeti geçen kişilerin biyografilerini ihtiva eden Tehzîbü't-Tehzîb adlı kitabının sonunda -tekrarlar çıkarıldığında- ancak üç yüz kadar kadın râvîn n tanıtıldığını görmekteyiz. Bunların büyük çoğunluğu da, sahâbe ve tâtiîn nesillerinden olan hanımlardır.

\section{Hicri Üçüncï Asırdan Sonra Hanım Muhaddislerin Çalışmaları}

Hicrî üçüncü ve dördüncỉ asırlar, Hadis ilmi açısından yoğun bir şekilde eser telifi çalışmıalarının yapıldığı dönemlerdir. Ancak hanım muhaddislerin telif işiyle fazla meşgul olmadıkları anlaşılmaktadır. Zira üçüncü asırda on, dördüncii asırda on yedi hanım, hadis öğrenim-öğretimi ve rivâyeti ile meşgul olduğt: halde, içlerinde eser telif eden herhangi bir kişi tespit edilememiştir. ${ }^{50}$ Hadis ilminin ana kaynakları olarak kabul edilen kitapların telifinden sonra, yani hicrî dördüncü asırdan itibaren, hadislerin

${ }^{46}$ İbn Hacer, Tehzî́b, VI, 543-544.

${ }^{47}$ Ibn Hacer, Tehzîb, VI, 560.

${ }^{48}$ el-Câmi 'fi'l-Cerh ve't-Ta'dîl, III, 474 .

${ }^{49}$ Ibn Hacer, Tehzîb, VI, 551. 'Iclî, kendisinden sadece oğlu Abdullah b. Mâlik' in rivayet naklettiği cl-'Âliye bint Sübey" 'in sika olduğ̣unu söylemiştir. Zehebî, Mîzân IV, 608, 611. Nesâî, kendisinden Ahmed (b. Abdillah) b. Yûnus'un rivâyet naklettiği Ümmüll-Esved elHuz.â' 'yye'nin sika olmadığılıa hükmetmiştir. K. ed-Du'afâ' ve'l-Metrûkin 'Halep, 1396' s. 117. Bu Ahmed'den başka, Enes b. Muhammed el-Müeddib, Abdurrrahmân İbn Amr elBecelî ve Müslim b. İbrâhîm de ondan rivâyet etmiştir. 'Iclî , onu için "Kûfe'li sika bir kişi" demektedir. İbn Hacer, Tehẩb, VI, 565. Adının Fâhıte veya Habîbe olduğu söylenen $\mathrm{Hz}$. Ali'nin odalığı Ümmü Mûsâ hakkında 'Iclî "Kûfe'li sika bir tâbiî" derken, Dârekutnî onun rivâyetinin düzgün (müstakîm) olduğunu, i'tibâr için tahriç edilebileceğini bildirmektedir. İbn Hacer, Tehzîb, VI, 577.

st) Biyografileri için bkz. Bolelli, s. 165-176. 
yerine eserlerin rivâyeti söz konusu olmaya başlamıştır. Artık kadın muhaddisler de, ağırlıklı olarak bu yönde hizmete yönelmişlerdir. Şimdi onların bu dönemdeki faaliyetlerinden bahsetmek istiyoruz.

\section{A. Bazı Meşhur Muhaddislerin Hanım Hocaları}

1. el-Hatîbü'l-Bağdâdî, Ebû Bekr Ahmed b. Ali (463/1071)

Târîhu Bağdâd'ın sonunda çoğunlukla kendi hocalarının rivâyet aldığı otuz iki kadın muhaddise yer vermiştir. Misal olmak üzere bunlardan birkaçını zikretmek istiyoruz. O, "doğru sözlü" olarak tavsif ettiği Fâtıma bint Hilâl'den hadis yazdığını bildirir. Sika olduğunu belirttiği Fâtıma bint Muhammed'den ise, doğrudan hadis dinlemek nasip olmamış, ondan Ebû Tâhir Muhammed b. Ahmed vâsıtası ile rivâyet etmiştir. Hatîb ve arkadaşları, kâdî Ebü'l-Kâsım et-Tenûhî'nin evinde, Tâhire bint Ahmed (436/1044)'den hadis dinlemişlerdir. ${ }^{\text {S1 }}$ Hadis yazdığı vâize Hatîce bint Mûsâ (437/1045)'yı "sika, sâliha, fâzıla" şeklinde tanıtır. Hatîb ve arkadaşları, kâdî Abdülvâhid b. Muhammed'in kızı Süteyte (447/1055) ile vâize Hatîce bint Muhammed (460/1067)'den de hadis yazmışlardır. ${ }^{52}$

Böylece Hatîb, Bağdat'ta bulunan otuz iki kadının beşinden bizzat hadis yazmış, geri kalanlardan da hocaları vasıtasıyla rivâyet etmiştir. Verdiği bilgiler, o dönemde Bağdat'ta hadis eğitim-öğretiminde, kadınların faal olduklarını göstermesi açısından önemlidir. Zikrettiği hanım muhaddisler için; sika, sâdıka, sâliha, fâdıla gibi övücü ifadeler kullandığı görülmektedir.

\section{Abdülğâfir b. İsmâîl el-Fârisî (529/1134)}

Abdülğâfir, el-Hâkim en-Neysâbûn'nin Târîhu Neysâbûr'una es-Siyâk adında tek ciltlik büyük bir zeyil yazmıştır. Bu zeyilde, Hâkim'in kitabını sona erdirdiği tarihten (h. 380 civarı) itibaren 510/1116'ya kadar Neysâbûr'da bulunan 1699 muhaddis tanıtılmaktadır. ${ }^{53}$ İbrâhîm b. Muhammed esSarîfînî, Siyâk'tan otuz civarında biyografiyi hazfederek, el-Müntehab'ını oluşturmuştur. Bu eserde, toplam yirmi iki hanım muhaddisin kısa hal tercümesi vardır.

Âişe bint Ebî Osmân (504/1110)'ın, babasından, amcasından ve zamanındaki hadis hocalarından birçok hadis malzemesi semâ edip, rivâyet etmiştir. ${ }^{54}$ Ilimle meşhur bir âileden gelen Hatîce bint İsmâîl (488/1095), sekiz-dokuz yaşlarında Ebû Nasr Ömer b. Abdilazîz'den semâ edip, sonra ondan rivâyet etmiştir. Babası, ona ve kız kardeşlerine bazı muhaddislerden

\footnotetext{
"I Târihu Băgdâd, XIV, 445,

${ }^{52}$ Târîhu Bağdâd, XIV, 446, 447.

53 'Umerî, Ekrem Ziyâ, Mevâridü'l-Hatîbi'l-Băgdâdî fi Târîhi Bağdâd 'Riyâd, 1405/1985' s. 269-270

${ }^{54}$ Sarînîi , İbrâhîm b. Muhammed, el-Müntehab min Kitâbi 's-Siyâk 'Beyrut, 1414/1993's. 187.443 .
} 
semâ ettirmiştir. ${ }^{55}$ Hâfız Ebì'l-Hasen'in kız kardeşi Dürdâne, dedesinden, ninesinden, babasından ve annesinden hadis semâ etmiştir. $O$, çocukluk döneminde Ebû Hâmid el-Ezherî'den hadis dinlemiştir. ${ }^{56}$ Buhârî'nin Sahîh'ini rivâyet hususunda: otorite kabul edilen, Mekke'de ikâmet edip orada ölmüş olan, Kerîme bint Ahmed el-Merveziyye (463/1071), semâ1 olan bütün eserlerin rivâyeti için, Abdülğâfir ve arkadaşlarına icâzet vermiştir. ${ }^{57}$

\section{Ebû Sa'd Abdülkerìm b. Muhammed es-Sem'ânî (562/1166)}

Sem'ânî, hocalarını tanıtmak için yazdığı Tahbîr'inin sonunda, ${ }^{58}$ kendilerinden hadis semâ ettiği veya yazdığı yahut icâzet aldığı yetmiş tane hanım hocasına yer vermişitir. Tanıtımlarda; onların ahlâk, ibâdet, ilim ve rivâyetteki yüksek derecelerini övmektedir.

Biyografilerin büyük tir kısmında göze çarpan husus onların ilim ve rivâyetle meşhur âilelere mensup olmaları ve dönemin büyük muhaddis ve âlimleriyle irtibatlarının bulunmasıdır. Babaları, onları muhtelif yerlere beraberlerinde götürerek, muhaddislerden semâ etmelerini yahut icâzet almalarını sağlamaktadırlar. Sem 'ânî, tanıtığı hocalarının bir kısmından bir veya birkaç cüz hadis semî ettiğini/yazdığını bildirmektedir. Bir çoğundan da, belli sayıda veya birkaç varaklık hadis semâ etmiş/yazmıştır. Sem 'ânî'nin döneminde, hadis kitap ve cüzlerinin rivâyeti söz konusu olduğu gibi, hadislerin tek-tek rivâyetinin de devam ettiği anlaşılmaktadır. ${ }^{59}$

Sem'ânî'nin hanım hocaları değişik şehirlerdendir. Bu durum, Sem'ânî'nin hadis tahsili iç̣in birçok yere seyahat ettiğini gösterdiği gibi, o dönemde İslâm âleminin muhtelif yerlerinde hadis rivâyetiyle ilgilenen kadınların bulunduğunu da ortaya koymaktadır. Bu şehirler; İsbehân,

ss Sarîfinî, s. 232-233.

\$6 Sarîfînî, s. 235. Ebû Ali ed-1)ckkâk'ın kızı Fâtıma ile Ebü'l-Kâsım el-Kuşeyrî'nin kızı Kerîme'nin biyografileri nispıtten uzundur. (s. 458-459; 468-469) Kuşeyñ, kızına birçok hadis kitabı semâ ettirmiştir. Bunlar arasında, el-Hasen b. Süfyân'ın Müsned'i de vardır. Kerîme, bu eserin tamamını Ebû İshâk el-Ürmevî'den semâ etmiş, sonra onu rivâyet etmiştir.

${ }^{57}$ Sarîfiñ̂, s. 467. Diğer hanımlàr için bkz. s. 183, 187, 228, 233, 239, 246, 268-69, 276, 294$95,443,459-60,469,516$.

${ }^{58}$ Sem‘ânî, Ebû Sa'd Abdülkerìm b. Muhammed, et-Tahbîr fi'l-Mu'cemi'l-Kebîr (Bağdat, 1395/1975) II, 396 vd.

59 Neysâbûr'lu Ümmü'l-Hayr (532/1137), İsbehân'lı Fâtıma bint Abdillah (524/1130) ve Fâtıma bint Muhammed (53:1/144), Sem 'ânî'nin uzun ömürlü hanım hocalarından olup, önemli hadis kitaplarını âlî isnatla rivâyet eden meşhur kađınlardır. (Tahbîr II, 430-431; 429; 432) Sem ânî, Lüveyn líkaplı Muhammed b. Süleyman'ın hadis cüzünü/nüshasını dört ayrı hanımdan semâ etmiştir. (Il, 407, 412,414, 425) Yine bir hanımdan Ebû Hafs elFellâs'ın, diğer birinden d: Ebü'l-Abbâs es-Serrâc'ın rivâyetlerini ihtivâ eden cüzü yazmış/semâ etmiştir. (II, 413, 427) 
Neysâbûr, Herât, Serahs, Hemezân, Bûşenc ve Dımaşk'tır. Biyografi sayısı çokluğu bakımından İsbehân ilk sırayı almaktadır, sonra Neysâbûr gelir. Semânî, buralarda görüştügü hocalarından hadis yazdığ $1 /$ semâ ettiği yahut kendisine icâzet yazıldığı tarihleri de kaydeder.

4. Ebüi'l-Kâsım Ali b. el-Hasen ed-Dımaşkî (571/1175) ve Ebû Tâhir Ahmed b. Muhammed es-Silefi (576/1180).

Sem'ânî ile çağdaş olan bu iki muhaddis, çok sayıda kadından rivâyet eden hadisçiler arasında sayılır. İbn Asâkîr, kadın hocaları için yazdığı $M u^{\prime}$ cemü'n-Nisvân'ında kendisinden hadis aldığı seksen küsur hanımı zikretmiştir. ${ }^{60}$ Silefî'nin talebelerinden birisi, onun kadın hocalarının isimlerini alfabetik tertiple bir araya getirmiştir. ${ }^{61}$

5. Ebô Muhammed Abdülazím b. Abdülkavî el-Münzirî (656/1258),

Et-Tekmile li Vefeyâti'n-Nakale'sinde; Kâhire, İskenderiyye, Dımaşk, Bağdat, İsbehân, Neysâbûr, Hemezân, Harrân gibi değişik yerlerden çok sayıdaki hanım hocasının biyografisine yer verir. ${ }^{62} \mathrm{O}$, bunların bir kısmından hadis semâ ederek, çoğunluğundan ise icâzet almak suretiyle istifade etmiştir. Mısır'lı ve Suriye'li hocalarının bir kısmı ile görüşmüş, diğer yerlerdekilerden ise icâzet almıştır. Dolayısıyla, zikrettiği hocalarının çoğunluğunu, icâzet aldığı hocaları teşkil etmektedir. ${ }^{63}$ Münzirî, kendi döneminde, muhtelif şehirlerdeki kadın muhaddislerden büyük bir bölümünü zikrederek, onların eğitim-öğretim ve ilmî araştırmalardaki katkılarını göstermeye çalışmıştır.

${ }^{60}$ Zehebî, Tezkire, IV, 1328. Târîhu Dımaşk'ın son iki cildinde, bir rivâyeti veya şiiri bulunan ve ibâdetle meşhur hanımların biyografileri vardır. Ibn 'Asâkir, burada, bazı kadın muhaddisleri tanıtmakta, bunlardan görüştüğü ve hadis semâ ettiği/yazdığı kişlere işaret etmektedir. O, semâının sahîh olduğunu belirttiği Emetü'l-Azîz'den bazı hadisleri yazmıştır. (LXIX, 241) Fâtıma bint Ali b. el-Huseyn'in evinde 526 senesinde ona bazı hadis cüzlerini okumuştur. (LXX, 34) Sûfî ve âlim Melike bint Dâvûd, bütün hadislerinin rivayeti için Ibn 'Asâkir'e icâzet vermiştir. (LXX, 127) Diğer hanım muhaddisler için bkz. LXIX, 45; LXIX, 167-168; LXIX, 190-191.

${ }^{61}$ Kettânî, Abdülhayy b. Abdilkebîr, Fihrisü'l-Fehâris ve'l-Esbât 'Beyrut, 1406/1986' II, 995. Silefî'nin kadın hocalarından bazılarının isimleri için bkz. Zehebî, Nübelâ, XXI, 9-12. Silefî, Hatîce bint Ahmed (526/1132)'in hocalarından rivâyet ettiği bütün hadisleri ona okumuştur. Meşhûr b. Hasen, s. 37. Lâmi'a bint Sa'îd, İsbehân'da hadis dinledig̣i hanımlardan biridir. Silef̂̃ ona Ibn Seleme'den icâzet yoluyla rivâyet ettiği Fevâid'i okumuştur. Silefí, el-Vecîz fí Zikri'l-Mücâz ve'l-Mücîz, Beyrut, 1411/1991, s. 157.

${ }^{62}$ Münzin̂́nin otuz küsur hanım hocasının isimlerini topluca görmek için bkz. Meşhûr b. Hasen, s. 39-44.

${ }^{63}$ Münziñ, kendisine 595/1199 yilında icâzet veren Kerîme bint Abdilvehhâb (641/1243) ile Dımaşk'ta ikinci defa görüşerek, ondan hadis scma etmiştir. Bu hanımın altmış sene gibj uzun bir müddet hadis rivâyet ettiği bildirilir. Yine, uzun yıllar Dımaşk ve Kâhire'de hadis okutan Fâtıma bint Sa‘d (600/1203) da, Münzirî’ye icâzet veren hanımlardandır. Münzirî onu "çok ilim yaydı" cümlesiyle övmektedir. Meşhûr b. Hasen, s. 40-41. 


\section{Ebû Abdillah Muhaınmed b. Ahmed ez-Zehebî (748/1347)}

Zehebî'nin el-Mu'cemui'l-Kebîr' indeki 1043 hocasından 105 tanesi kadındır. ${ }^{64}$ Bunların biyograjïleri, ilgili harflerin sonlarında yer alır. Zehebî, bu kitabında, yüz-yüze görüßștüğü veya icazet aldığı hocalarını tanıtmaktadır. Görüşmediği hâlde kendisine icâzet veren hocalarına yer vermesinin normal karşılanmasını ister. Zira, İbn 'Asâkir'in $M u$ 'cem'inde de, semâ ve icâzet hocaları karışık olarak verilıniştir. ${ }^{65}$ Zehebî, İbn Abdiddâim'den rivâyet eden bir çok kadın hocasına, herialde bunların hepsinin bulunduğ bir mecliste, ondan naklettikleri rivâyetlęri okumuştur. ${ }^{66}$ Zehebî'nin, ilmî seyahatlerinde kadın muhaddislerle görüşmeye özen gösterdiğine dair misaller vardır. ${ }^{67} \mathrm{Kü-}$ çük yaşlardaki çocukların, babaları tarafından hadis derslerine götürülerek, onlar için âlî semâ kayıtları temin etme âdetinin, muhaddisler arasında yaygin olduğu bilinmektedir. 'Zehebî, bu konuda gevşeklik gösteren babalara dikkat çeker. Meselâ Hatîce bint Ahmed ile 'Acîbe bint Muhammed'in babaları, onlara küçük yaşlarında bazı muhaddislerden semâ ettirmemişlerdir. ${ }^{68}$

\section{Ebü'l-Fadl Ahmed b. Ali b. Hacer el-Askalânî (852/1448).}

Sehâvî, İbn Hacer'in kendilerinden rivâyet aldı̆̆ 1 ve istifade ettiği hocalarını; "hadis semâ ettikleri, icâzet verenler ve müzâkere yoluyla bilgi aldıkları" şeklinde üç grubă ayırıp, liste halinde isimlerini sayar. Buna göre toplam hoca sayısı 630'dur. Bunlar arasında; semâı olan on dokuz, icâzeti olan otuz altı ve bir tane cle müzâkere esnasında bilgi aldığı olmak üzere, toplam. 56 tane kadın ismi zikredilir. ${ }^{69}$ İbn Hacer'in, Hatîce bint İbrâhîm $(803 / 1400)$ 'e okuduğu/semâ ettiği kitap ve cüzlerin sayısı ise yirmi üçü

${ }^{64}$ Beşşâr 'Avvâd Ma'rûf, ez-Zehebî ve Menhecühû fi Kitâbihî Târîhi'l-islâm 'Kahirc, 1976' s. 65 .

${ }^{65}$ Zchebî, Mu 'cemü Şüyûh'z-Zchє bî 'Beyrut, 1410/1990's. 13.

o6 Zehebî, Mu'cem, s. 176, 2C3, ayrıca bkz. s. 183. Zehebî, el-Huseyn b. ez-Zebîdî (631/1233)'den rivâyet nakledı:n birçok hanımdan da semâ etmiştir. Mucem'inde onlardan bir kısmının isimlerini topluca rikretmektedir. (s. 187)

${ }^{67}$ Mesclâ kendisine icâzet veren Seyyide bint Mûsâ ile görüşmek için (Misır'a) doğru yola çıkmış. Ancak 695 yılının Receb ayında Filistin'de iken bu hanım vefat etmişti.(s. 236) Zehebî, bir rivâyeti, üç ayrı şehirde üç ayrı hanıma okumuştur: Kudüs'te Zeynep bint Şükr'e, Mısır'da Zeynep bint Süleymân'a ve Dimaşk'ta Hatîce bint Ğanîme'ye. Bu üç hanım, o rivâyeti, İbnü'l-Letí diye meşhur olan Ebü'l-Müneccâ Abdullah b. Ömer'den (635/1237) nakletmektedir. (s. 199)

${ }^{\circ}$ Zehcbî, $M u^{\prime} c e m$, s. 181; Nülılâ, XXIII, 233. Muhaddisler, kendisiyle görüşmek üzerc Zeynep bint Ahmed b. Ömer için Bcytü'l-Makdis'e (Kudüs'e) gitmişlerdir. Zamanındaki âbid kişilerden olan bu hanım. Mısır'da ve başka yerlerde hadis rivâyet etmiş ve bir müddet de Medîne'de bulunmuştur. Mu'cem s. 199. Şühde bint Ömer, Mısır. Dımaşk ve Halep'te hadis rivâyet etmiş, nihâyet doksan küsur yaşında iken 709 yılı içinde Halep'tc vefat etmiştir. Mu'cem s. 240.

(H Sehâvî, Muhammed b. Abdirrahmân, el-Cevâhir ve'd-Dürer 'Kahire, 1406/1986' I, 135 177. 
bulmaktadır..$^{70}$ Uzun ömürlü olması sebebiyle "müsnidetü'd-dünyâ" lâkabını alan Fâtıma bint Muhammed (803/1400)'e okumak suretiyle ondan 250 civarında kitabın/cüzün rivâyet hakkını almıştır. Listenin sonunda, "kaydedilmiş olarak bunları bulduğunu, aslında bu listenin rivâyet hakkını aldığı eserlerin tamamını kapsamadığı" tahminini belirtir. ${ }^{71}$ İbn Hacer, Hâfız Ziyaüddîn elMakdisî (643/1245)'nin kitaplarının büyük bir kısmının rivâyet hakkını, onları bu hanıma okumak suretiyle elde etmiştir. Fâtıma bu eserlerin rivâyet hakkını et-Takî Süleymân'dan icâzet yoluyla almış; Süleymân da onları müellifinden semâ etmiştir. ${ }^{72}$

Âişe bint Muhammed b. Abdilhâdî (816/1413), Buhârî'nin Sahîh'ine Ebü'l-Abbâs el-Haccâr'dan, Müslim'in Sahîh'ine de Abdullah İbnü'lHasen'den semâ yoluyla sahip olmuştur. O, semâ ettiği ve icâzet aldığı kişilerden rivâyet eden son kişidir. Bu yüzden ölünce bütün bölgelerdeki muhaddisler âlî isnattan bir derece kaybetmişlerdir. Bu hanım, İbn Hacer'in Zeyn Hâtûn ve Râbia adlı kızları ile oğlu Muhammed'e icâzet vermiştir. İbn Hacer, onun ve kız kardeşi Fâtıma'nın, Haccâr'dan semâ ettiği birçok hadis kitabını/cüzünü onlara okumuştur. Bunlardan yirmi tanesini misal olarak zikreder. $^{73}$ İbn Hacer; Misır, Halep, Hama ve Hıms'lı âlimlerden bu Fâtıma'ya (803/1400) icâzet verenlerin isimlerini sayarak, kardeşi Âişe ile birlikte değil, sadece ona okuduğu kitap ve cüzlerin geniş bir listesini, ilgili isnatlar ve açıklamalarla bize sunar. Bunların sayısı altmış eseri bulmaktadır. $^{74}$

70 İbn Hacer. el-Mecma'u'l-Müessis li'l-Mucemi'l-Müfehris, Beyrut, 1413/1992, I, 572-587. Kâhirc'li ve Sam'lı pek çok meşhur muhaddisin kendisine icâzet verdiği Sâre bint Ali (805/1402), Kâhire, Dımaşk ve Kudüs'te bulunmuş, yetmiş yaşından sonra Kâhire'de vefat etmiştir. Bu hanım, İbn Hacer'in kızı Zeyn Hâtûn'a icâzet vermiştir. İbn Hacer onunla görüşerek, kendisine beş kitap/cüz okumuştur. Müessis I, 610-615. İn Hacer, Meryem bint Ahmed'den (805/1402) kırktan fazla kitabın/cüzün rivâyet hakkını almıştır. Bunlar arasında, Muhammed b. Eslem'in Kitabü'l-Erba'în'i de vardır. Ancak İbn Hacer, ona bu kitabın muhtevasını değil, sadece müellifine ulaşan isnat zincirini okumuştur. (II, 559-571)

"İbn Hacer, Müessis, II, 389-434.

${ }^{72}$ İbn Hacer, Müessis, II, 431-434.

${ }^{73}$ İbn Hacer, Müessis, II, 350-357. Ibn Hacer, kızlanı başta olmak üzere hanım yakınlarının hadis tahsiline özen gösteren bir âlimdir. Ancak kızlarının çoğu erken vefat ettikleri için, hadis ilminde meşhur olmamışlardır. Zeyn Hâtûn (833/1429), İbn Hacer'in torunu diye meşhur olan Yûsuf b. Şâhîn'in annesidir. Yûsuf, dedesinin kitaplarına büyük önem verip, onların sonraki nesillere ulaşması için güzel hizmetler îfâ etmiştir. Abdülmün'ım, Şâkir Mahmûd. Ibn Hacer el-'Askalânî ve Dirâsetü Musannafâtihî 'Bağdat, 1978' I. 96 vd.; Meşhûr b. Hasen, s. 126-129.

74 Ibn Hacer, Müessis, II, 368-388. Listede Hadis ilminin bütün branşlarından kitaplar mevcuttur. İbn Hacer'in Fâtıma'ya okuduğu eserler arasında, Ali b. Hucr b. İyâs'ın rivâyetlerini ihtiva eden kitabın ilk cüzü de vardır. Fâtıma onu, sckizi hanım olan on yedi 


\section{Hicrî sekizinci ve dokuzuncu asrın hanım muhaddisleri}

İbn Hacer, hicrî sekizinci asrın ricâli için yazdı̆̆ı ed-Dürerü'l-Kâmine adlı eserinde, 170 tane kadıı muhaddisin kısa biyografisini sunmuştur. $O$, bunların çoğunun derslerine katılmış veya kendilerinden icâzet temin etmiştir. Bu kadın muhaddislerin biyografileri için, kaynak olarak daha çok $m u^{\prime}$ cem-meşyaha kitaplarınıı kullanıldığı dikkat çekmektedir. Zira, genel tabakât/terâcim kitaplarında, çoğunlukla meşhur olan kişilere yer verilirken, mu'cem-meşyaha kitaplarının müellifleri, her hangi bir bilgi öğrendikleri şahısların tümünü -erkek olsun kadın olsun- zikretmeye önem vermişlerdir. ${ }^{75}$

Ibn Hacer, 773-850/1371-1446 yilları arasında meydana gelen olaylar ve vefat eden âlimler için yazdığı Enbâü'l-Ğumr bi Ebnâi'l-'Umr adlı kitabında ise, birçoğu yine kendi hocası olmak üzere, çok sayıda hanım muhaddisi zikretmiştir. ${ }^{76} \mathrm{Bu}$ iki kitaptaki hanım sayısı, hicrî sekizinci ve dokuzuncu asırlarda kadın muhaddis sayısının önemli ölçüde arttığını gösterir. Ayrıca, İbn Fehd (371/1466)'in, 1100'den fazla hocasını zikrettiği Mu'cemü's-Şüyûh'unda, 130 tane kadın muhaddisin bulunması da buna delil sayılabilir.

Sehâvî (902/1496), dokuzuncu asır ricâli için yazdı̆̆ı kitabın sonunda 1000 'den fazla hanımın kısa hal tercümesini vermiştir." Bunların içinde, küçük yaşta iken ölen kız çıcukları ve Hadis ilmiyle iştigâli olmayanlar da vardır. Fakat bu sayı, hicrî dokuzuncu asırda hadis ile ilgilenen çok sayıda hanımın olduğunu göstermesi açısından önemlidir. Sehâvî, birçok kaynağı tarayarak, bu kadar çok sayıda hanımın -kısa da olsa- biyografisini hazırlamıştır.

Hicrî beşinci asırdan sonra, muhaddisler tarafından icâzetnâme usûlü geniş bir şekilde kullanılmışıtır. İlimle meşhur bir âileye mensup kişiler, çok sayıda âlimden icâzet temin ederler. ${ }^{78}$ Sehâvî, biyografi sahibinin hocalarının isimlerini, büyük ölçüde gördügü icâzetnâmelerden nakleder. Çoğu yerde, bu icâzetnâmelerin hangi tarihte yazıldığını da açıklar. Tabii, daha önce telif edilen kitaplardan da yararlanmıştır. ${ }^{79}$ Kitaptaki toplam sayıya göre az

hocadan semâ etmiştir. Bu on yedi kişinin tamamı, onu Ahmed b. Abdiddâim'den semâ etmiştir. (II, 375, 376)

${ }^{75}$ Emîne Muhammed Cemâleddî̀, "Terâcimü'l-Muhaddisât fíl'- 'Asri'l-Memlâkî" s. 481-484. (Katar Üniversitesi, Sünnet ve Sîret Araştırmalanı Merkezi Der., sayı: 6, yıl: 1412/1992-3, s. 469-490)

${ }^{76}$ Ibn Hacer'in bu iki eserde geçen hanım hocalarından bir kısmının isimleri için bkz. Bolelli, s. 208-209, dn. 68 .

${ }^{n}$ Sehâvî, ed-Dav'ü'l-Lâmi' li Ehli'l-Karni't-Tâsi' 'Beyrut, ts.' XII, 2-167.

${ }^{77}$ Sehâvî, bazı hanım muhaddislır için şu şekilde bir açıklamada bulunmaktadır: "Hadis ve rivâyetle meşhur bir âiledendir. Dolay'sııla büyük ihtimalle önceki âlimlerden icâzet almış olmalıdır." (bkz. nr. 29, 249, 307)

79 Hocası Ibn Hacer'in $M u^{\prime}{ }^{\prime}$ c’m'i ile Enbâ'sı, Takıyyüddîn el-Fâsî'nin'nin kitabı -ki muhtemelen el-'lkdü's-Semîn'idir- Ibn Fehd'in Mu'cem ve Vefeyât'ı ile Makrîzînin 'Ukâdu 
olmasına rağmen, kadın muhaddislerin bilhassa uzun ömürlü olanlarından, ihtilâta (zihin fonksiyonlarının bozulması) maruz kalanlar görülmektedir. Sehâvî, zaman zaman bunlara işaret etmektedir. ${ }^{80}$

Süyûtî (911/1505), el-Müneccem fi'l-Mu'cem adlı kitabında, kendilerinden hadis semâ ettiği veya icâzet aldığı 150 kadar hocasını üç tabakaya ayırarak tanıtmaktadır. Bunlar arasında hanım hocaları da vardır. O, dördüncü tabakadaki küçük hocalarından hiç kimseyi bu kitabına almamıştır. Onlar, Ebû Zür'a b. el-'Irâkî (826/1422), İbnü'l-Cezen̂́ (833/1429) ve elBürhân el-Halebî (841/1473)'nin talebeleri olan kişilerdir. ${ }^{81}$

Hicri onuncu asırdan itibaren kadınların Hadis ilmine ilgileri oldukça azalmıştır. Çünkü bu asırdan itibaren yazılan biyografi kitaplarında, kadın muhaddislerin sayısının bir düzineyi geçmediği görülmektedir. ${ }^{82}$ Zamanımızda, ülkemizde ve diğer İslâm ülkelerindeki ilâhiyât fakültelerinde, sayıları az olsa da, Hadis alanında akademik çalışma yapan hanımlar vardır. Dolayısıyla, kadınların Hadis ilmine ilgisinin devam ettiğini söylememiz mümkündür. Ayrıca, önceki asırlarda, eser telif eden hemen-hemen hiç kadın muhaddis yokken, bugün Hadis ilmiyle iştigâl eden hanımların, kendi telifleri olan akademik çalışmaları bulunmaktadır.

\section{B. Hanım Muhaddislerin Hadis İlmindeki Hizmet Alanları 1. Hadis ve Hadise Dair Eserlerin Rivâyeti}

Kadınlar, hicrî ilk üç asırda, hadislerin sonraki nesillere aktarılması hususunda, önemli bir görev yaptıkları gibi, üçüncü asırdan itibaren de hadise dair eserlerin rivâyeti işinde büyük hizmet îfâ etmişlerdir. Hadis kitaplarının müelliflerine ulaşan muttasıl isnatlarla rivâyet edilmesi, hadisçilerce çok önemli görülmüştür. Özellikle de, bunun âlî isnatla olması, yani eserin müellifine en az sayıda râvî ile ulaşmak, onların arzu ettikleri bir husustur. Bu yüzden, daha çocuk yaşlarında iken hadis kitap ve cüzlerinin okunduğu derslerde hazır bulunan ve uzun ömürlü olan kişilerden, o eserlerin rivâyet hakkı elde edilmeye çalışılır. Hanım muhaddislerin bir çoğunun bu şekilde olduğu görülmektedir. Onların, biyografilerinde, müsnide (âlî isnada sahip), mu'ammere (uzun ömürlü) gibi vasıflarla zikredildikleri dikkat çeker.

(=Dürerü'l-'Ukûdi'l-Ferîde) -bilhassa vefat tarihleri hususunda- kullandığı başlıca kaynaklardır.

${ }^{30}$ Meselâ bkz. nr. 64, 108, 205, 702. Ribât, medrese gibj hayır kurumları inşâ ettiren ve vakıfları olan hanımlar için bkz.nr. 621,639,913, Mekkc'de el-Meğânî ve el-'Avâlim adlı iki dergâhta şeyhlik yapan hanımlar için bkz. nr. 34, 38, 551 .

${ }^{81}$ Kettânî, Fihris, 11, 594. Süyûtî'nin hanım hocalarından bazılan için bkz. Bolclli, s. 209, dn. 70. M. Zihni Efendi, Meşâhiru'n-Nisâ 'Istanbul, 1296/1879' adlı eserinde, Müneccem'de geçen hanım muhaddislere de yer vermektedir.

${ }^{82}$ Meşhûr b. Hasen, s. 103. 
İbn Nukta (629/1231), Takyîd adlı eserini, Hadis ilmi ile iştigâl edenlerin müstağnî kalamaya.cağı meşhur hadis kitaplarını rivâyet edenlere hasretmiştir. ${ }^{83}$ Önemli hadis kitaplarının rivâyet hakkına sahip kişilerin tanıtıldığı bu kitabın sonunda, on iki tane hanım muhaddise yer verilir. Bunların her biri, semâ yoluyla bazı hadis kitaplarının rivâyet hakkını elde etmişler; muhaddisler de, kıraat veya icâzet yoluyla bu hakkı kendilerinden devralmışlardır. İbn Nukta, onların bazıları ile görüşüp, sahip oldukları hadis malzemesinin rivâyet hakkını elde etmiştir.

Mekke'de Kerîme bint Ahmed el-Merveziyye (463/1071), Buhârî'nin Sahîh'ini Ebü'l-Heysem Küşmîhenî'den rivâyet etmiştir. el-Hatîbü'l-Bağdâdî, Sahîhu'l-Buhârî́yi ondan semâ edenler arasındadır. ${ }^{84}$ Fâtıma bint Abdillah el-Cûzdâniyye (52.4/1130), İbn Rîze'den (Muhammed b. Abdillah) Tabarânî'nin büyük ve küçiık $M u^{\prime}{ }^{\prime} c e m$ 'i ile Nu'aym b. Hammâd'n Fiten'ini rivâyet etmiştir. ${ }^{85}$ İsbehân'lı Af̂̃fe bint Ahmed (606/1209), onları Fât1ma'dan, İ́n Nukta da bun!arı ve başka eserleri Afiffe'den semâ etmiştir. ${ }^{86}$ Neysâbûr'lu Fâtıma bint Ali (532/1137), Abdülğâfir b. Muhammed el-Fârisî'den Müslim'in Sahîh'inin tamamını, Hattâbî'nin Ğarîbü'l-Hadîs'ini ve başka eserleri semâ etmiştir ${ }^{87}$ 'Ebü'l-'Alâ' el-'Attâr'ın kızı 'Âtike (609/1212) ise, Ebû Dâvûd'un Sïnen'ini, Ebû Bekr Hibetüllah b. el-Ferec'den dinlemiş ve onun tamamını Bağdat'ta rivâyet etmiştir. ${ }^{88}$

Takıyyüddîn el-Fâsî (332/1428), İbn Nukta'nın kitabına bir zeyil çalı̧̧ması yapmıştır. O, İbn Nıkta'nın esas aldığı kitaplara bir çok yeni kitap eklemiş ve kendi zamanına kadar bu kitapların râvîleri olan kişileri ilâve

${ }^{83}$ Bu kitapların listesi için bkz.. İbn Nukta, Ebû Bekr Muhammed b. Abdilğanî, et-Takyîd li Ma'rifeti Ruvâti's-Sünen ve'l-Mesânîd 'Beyrut, 1408/1988' s. 26.

\&s Ibn Nukta, s. 499.

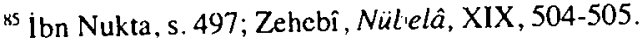

${ }^{80}$ I bn Nukta, s. 500-501.

${ }^{87}$ Ibn Nukta, s. 498.

${ }^{28}$ Ibn Nukta, s. 500. Kadınlar tarafından rivâyet edilen eserlerden bazıları şunlardır: Ebû 'Avâne'nin Müsned'i, Müsedded'in Müsned'i, Ebû Ya'lâ el-Mevsılî'nin Müsned'i, Ebû Bckr b. Lâl'ın Mekârimü'l-Ahlâk'ı ve Ebii'l-Kâsım el-Kuşeyrînin Risâle'si ile Mi'râc'ı: (s. 497 501) Dımaşk ve Mısır'da hadis rivâyet eden Fâtıma bint Sa'd'den (600/1203) birçok muhaddis rivâyet almıştır. (s. 498-499; Zehebî, Nübelâ, XXI, 412-413) Isbehân'lı Âişe bint Ma'mer'den (607/1210) Ibn Nukta ve başkalan rivâyet etmişlerdir. İbn Nukta İsbehân'da ondan Ebû Ya'lâ el-Mevsılî'nin Müsned'ini ve bazı hadis cüzlerini semâ etmiştir. (s. 499; Zehcbî, Nübelâ, XXI, 499-500) Muhaddisler, zamanının müsnidesi İsbchân'lı 'Aynü'şŞems bint Ahmed es-Sekalïyye'den (610/1213) semâı olan eserleri rivâyet etmişlerdir. (Zehebî, Nübclâ, XXII. 23-24) Horâsân'ın müsnidesi Neysâbûr'lu Zeyneb bint Abdirrahmân'ın (615/1218) hocalarından semâ ve icâzet yoluyla aldığı rivyetleri, İbn Nukta, Birzâlî, İbnü's-Salàh gibi hadiş̧iler ondan nakletmişlerdir. İbn Nukta, s. 501; Zehebî, Nübelâ, XXII, 85-8í. 
etmiştir. ${ }^{89}$ Bu zeyil, vefat tarihleri h. 497-870 arasında olan toplam 1906 kişiyi kapsar. Hadis kitapları râvîsi olan 104 kadın, kitabın sonunda tanıtılır. Rivâyet edilen eserler listesinde, hadis literatürünün değişik türlerinden kitaplar mevcuttur.

Fâsî, mucem türü eserlerden, İbn Nukta'nın zikretmediği bir çok kitabın râvîsini toplamıştır. Muvatta'ın değişik nüshaları ile Kudâ'î'nin Müsnedü'sŞihâb'ını rivâyet eden kişiler onun ilâveleridir. Zikrettiği kişilerin hemen hepsi, rivâyet hakkına sahip oldukları kitapları ya sema etmiştir veya okumuştur. Çok azı, rivâyet ettikleri kitapları sema etmemiş olup, icâzet yoluyla almışlardır. Bazıları da, semâ ettikleri kitapların belli kısımlarını kaçırdıkları için, o bölümleri icâzet taniki ile rivâyet etmişlerdir. Fâsî, henüz tahdîs yaşına ulaşmadan önce bazı kitapların okunduğu derslere katılan bir çok kişiyi eserine almadığını söylemektedir.

Fâsî'ye göre, bazı kitapların râvîlerinin tamamını zikretmek imkânsızdır. Özellikle Buhârî'nin Sahîh'ini, Vezîre bint Ömer (716/1316) ve "Ebü’l-Abbâs el-Haccâr" diye bilinen Ahmed b. Ebî Tâlib (730/1329)'den dinleyenlerin sayısı oldukça çoktur. Bu iki âlim, Sahîhu'l-Buhârî'yi, Dımaşk ve Kahîre'de, talebelerine defalarca okumuştur."

'Acîbe bint Ebî Bekr (647/1249) muhtelif hocalardan önemli eserler rivâyet etmiştir. ${ }^{92}$ Zeyneb bint Mekkî (688/1289), Ömer b. (Muhammed b.) Taberzed'den altı eser dinlemiştir. ${ }^{93}$ Doksan dört sene yaşaması sebebiyle âlî isnada sahip olduğu için "müsnidetü'd-dünyâ" ünvanı verilen Zeyneb bint elKemâl Ahmed (740/1339), hocalarından icâzet yoluyla çok sayıda kitap ve âlî isnatlı cüz rivâyet etmiştir. Zamanındaki bir çok büyük muhaddis ondan semâ etmiştir. ${ }^{94}$ Cüveyriye bint Ahmed (783/1381) değişik hocalarından pek çok kitap semâ etmiştir. ${ }^{95}$ Fâtıma bint Ahmed (783/1381), baba dedesi Radiyyüddîn et-Taberî'den İbn Mâce hariç el-Kütübü's-Sitte'yi, İbn Hıbbân'ın Sahîh'ini, Tirmizî'nin Şemâil'ini ve daha başka kitap ve cüzleri

89 Fâsî, Muhammed b. Ahmed, Zeylü't-Takyîd fî Ruvâti's-Sünen ve'l-Mesânîd, Beyrut, 1410/1990. 1, 31-32.

${ }^{90}$ Fâsî, II, 357-397.

${ }^{91}$ Fâsî, I, 32-33.

${ }^{92}$ Zehebî, Nübelâ, XXIII, 233; Fâsî, II, 383.

${ }^{33}$ Tirmizî'nin Câmi 'i, Ebû Dâvûd'un Sünen'i, Ibnü'l-Mübârek'in Zühd'ü, Vâkıdî'nin Meğâzî́si, ez-Zübcyr b. Bekkâr'ın Kitâbü'n-Neseb'i ve el-Gaylâniyât. Ayrıca, Hanbel b. Adillah'tan Ahmed b. Hanbel'in Müsned'ini, Ebü'l-Hasen el-Kerâbîsî'den de İbnü's-Sünnî'nin 'Amelü Yevm ve Leyle'sini semâ etmiştir. Fâsî, II, 372.

91 İcâzet hocaları ve rivâyet ettiği eserlerden bir kısmının listesi için bkz. Fâsî, II, 366-367.

${ }^{95}$ Fâsî, II, 361-362; krş. Veliyyüddîn cl-'Irâkî, Ahmed b. Abdirrahîm, ez-Zeyl 'ale'l-'Iber fî Haberi Men 'Aber 'Beyrut, 1409/1989' II, 512-514. Muhaddislerin kendisinden çok semâ ettiği Cüveyriyc, diğer hocalarından daha başka eserler semâ etmiştir. Veliyyüddîn, zikrettiği eserlerin tamamını ondan dinlediğini ifade etmektcdir. 
semâ etmiştir. Takıyyüddînı el-Fâsî, Medîne'de ikâmet ederken ondan Sekâfíyyât' ${ }^{\prime}$ dinlemiştir. ${ }^{96}$

Böylece, Takyîd ve Zeyli, h. 9. asrın ortasına kadar, meşhur hadis kitaplarının râvîlerinden 2.:j00'den fazla kişiyi bize tanıtmış olmaktadır. Kadınların sayısı, yüzden biraz fazladır. Erkeklerin sayısına oranla bu rakam oldukça az olmasına rağmen, hanımların hadis kitaplarının rivâyeti işinde görev almış olmalarını göstermesi açısından yeterlidir. Ayrıca onlar, hadise dair önemli eserlere âlî isnatla sahip oldukları için, büyük muhaddisler o kitapların rivâyet hakkını kındilerinden almaya çalışmışlardır. Dolayısıyla bu hanımlar, kendilerinder rivâyet eden çok sayıda meşhur muhaddise hocalık yapmıs olmaktadırlar.

\section{Talebe ve hoca olarıı eğitim-öğretim faaliyetinde bulunma}

"Hadis ve hadise dair eserlerin rivâyeti", aslında, kişinin talebe ve hoca olarak yerine getirdiği bir faaliyettir. Yani, bir rivâyeti alma ve aktarma işinde, her zaman talebe-hoca münâsebeti söz konusudur. Rivâyet hakkını alan talebe, veren hoca konumundadır. Bu yüzden muhaddisler, en küçük bir bilgi öğrendikleri kişileri dăhi hocaları olarak görürler. Hadis tahsili yapmak isteyen kişi, hadise dair eserleri zamanındaki güvenilir hocalardan okuyarak ögrenecek, daha sonra usûlüne uygun olarak onları talebelerine aktaracaktır.

Kadın muhaddislerin e:ğitim-öğretim faaliyeti de bu şekildedir. Onların çoğu, hadis ilmiyle tanınan bir âileye mensup oldukları için, babaları ve diğer akrabalarından bu konuda büyük yardım görmüşlerdir. Muhaddisler, çocuklarına kendileri hadis okuttukları gibi; onları hadis derslerine götürmüşler ve dönemin âlimlerinden onlar için icâzet almışlardır. Kız çocukları, hadis kitaplarının âlî isnatlı rivâyet hakkına sahip olmalanı için, henüz yedisekiz, hattâ üç-beş yaşlarında iken derslerde hazır bulundurulmuşlardır. Bu konuda pek çok örnek vardır. Kadın biyografilerini ihtiva eden herhangi bir ricâl kitabı karıştırılırsa, bir çoğunun küçük yaşlarda hadis derslerine götürüldüğü görülecektir ${ }^{97}$ Mıhaddisler, hadis tahsili için yaptıkları seyahatlerde, kızlarını ve eşlerini de beraberlerinde götürmüşler; kimi hanımlar da

\%6 Fâsî, II. 384. Veliyyüddîn'c 'oöre, biri Medîne'de, diğeri Mekkc'de, aynı yılda vefat etmiş olan "Fâtıma bint Ahmed" ałlı iki aynı hanım muhaddis vardır. Veliyyüddîn ikisinden de semâ etmiştir. (II, 526, 527) Veliyyuüddîn'in zikrettiği diğer hanım muhaddisler için bkz. I, $60,65,84,93,115,139,166,180,199 ;$ II. $318,332,399,511,512$. Aynı yılda $(803 / 1400)$ vefat etmiş olan Fâtıma bint Muhammed et-Tenûhıye ile Fâtıma bint Muhammed elMakdisiyye çok sayıda hadis kitabı ve cüzü rivâyet eden meşhur hanım muhaddislerdendir. Fâsî, II. 389-390; 390-391.

9 Ibnü'l-Buhârî'nin torunu 'Sittü']-'Arab bint Muhammed (767/1365), dedesinin hadis derslerinde hazır bulunmuştır. Bu sayede çok sayıda hadis ve eserin rivâyet hakkına sahip olarak, onları öğrencilerine rivâyet etmiştir. Büyük muhaddisler ve hadis talebeleri, ondan semâ ederek, bu rivâyetleri yaymışlardır. Vcliyyüddîn, I. 199; Fâsî, Il, 374-375. 
deģişik beldelere giderek hadis hocaları ile görüşmüş ve gittikleri yerlerde hadis rivâyet etmişlerdir. ${ }^{98}$

Kadınlar da, erkekler gibi, semâ, kırâat, icâzet gibi eğitim-öğretim usulleri ile hadis öğrenip-ögretmişlerdir. Yazma hadis kitaplarının semâ kayıtlanı, talebe veya hoca olarak, ilgili kitabın okunduğu derslere katılmış olan kadın isimlerini de ihtiva eder. İbnü'l-Buhârî (690/1291)'nin Meşya$h a$ 'sında yer alan vesikalar, Şam'da bulunan Ömer câmiinde ve Halep'te yapılan hadis derslerine katılan kalabalık ögrenci grubu içinde, birçok kadının mevcut olduğunu göstermektedir. Bu eserdeki bir belgeye göre, "Ümmü Abdillah" diye bilinen hanım muhaddis, Şam'da elli kişiden fazla talebeyi ihtiva eden bir sınıfta 837/1433 yılında beş ders vermiştir. ${ }^{99}$

Hanımlar, belli bir dönem hadis tahsili gördükten sonra, birikimlerini talebelerine aktarmak için, evlerinde veya çeşitli müesseselerde hadis rivâyet etmişler, ders okutmuşlar ve icâzet vermişlerdir. Öyle ki, birçok meşhur muhaddis bile, onlardan çeşitli hadis kitaplarını okumuş veya sahip oldukları eserlerin rivâyet hakkı için kendilerinden icâzet almıştır.

Kerîme bint Ahmed el-Merveziyye (463/1071), Buhârî́nin Sahîh'ini okutma hususunda dönemin en salâhiyetli hadis hocası olarak tanınır. elHatîbü'l-Bağdâdî ve el-Humeydî gibi pek çok meşhur muhaddis bu kitabı ondan semâ etmiştir. ${ }^{100}$ "Irâk'ın müsnidesi" olarak bilinen, uzun ömürlü Şühde bint Ahmed (574/1178), âlî isnada sahip olmakla meşhur olduğu için, t́bn 'Asâkir, Sem'ânî, Ibnü'l-Cevzî gibi birçok muhaddis ondan okumuş ve icâzet almıştır. Onun Sahîhu'l-Buhârî ve diğer hadis kitaplarını okuttuğu dersleri kalabalık bir talebe grubu tarafından takip edilmiştir. ${ }^{101}$ Yine uzun ömürlü Vezîre bint Ömer (716/1316), Buhân'́nin Sahîh'ini, el-Huseyn b. elMübârek ez-Zebîdî (631/1233)'den Dımaşk'ın Sâlihiyye bölgesindeki elCâmi' i'l-Muzafferî'de semâ etmiştir. Bu hanım, Sahîh başta olmak üzere çok sayıda hadis kitabını rivâyet etmiş, kendisinden birçok muhaddis semâda bulunmuştur. ${ }^{102}$

Bu üç hanım muhaddis -yani Kerîme, Şühde ve Vezîre- bilhassa Buhârî'nin Sahîh'ini rivâyet hususunda gerçekten önemli simalardır.

\footnotetext{
98 Örneğin, Neysâbûr'lu Cumu'a bint Ahmed, Bağdat'a gelip birçok âlimden hadis rivâyet etmiştir. Târîhu Bağdâd, XIV, 442-3, 444. Ebû Sa'îd, kızı Ümmü'r-Rıdâ Râzıye'yi Irâk'a götürüp, oradaki âlimlerden hadis semâ ettirmiştir. Bu hanım, İsferâyîn, Sâva ve başka şehirlerdeki muhaddislerden de hadis semâ etmiştir. Meşhur muhaddis Ebü'l-Fadl Muhammed b. Tâhir el-Makdisî'nin kızı Dav'ü'n-Nehâr, Hemezân, Rey ve başka şehirlerdeki muhaddislerden semâ etmiştir. Sem'ânî, ondan Hemezân'da birkaç varaklık hadis dinlemiştir. Sem'ânî, Tahbîr, Il, 407, 419.

99 Sıddîkî, Muhammed Zübeyr, Hadis Edebiyan Tarihi 'trc. Y. Ziya Kavakçı, İstanbul 1966' s. 137.

${ }^{100}$ Zehebî, Nübelâ, XVIII, 233-234; Sıddîkî, s. 132.

${ }^{101}$ Zehebî, Nübelâ, XX, 542-543; Sıddîkî, s. 132-133.

${ }^{102}$ Fâsî, II, 397.
} 
Dönemlerinde birçok muhaddis, onlardan bu eserin rivâyet hakkını alabilmek için âdeta yarış etmişlerdir. ${ }^{103}$ Hanım muhaddisler, talebe veya hoca olarak; evlerde, ribatlarda, camilerde ve dâru'l-hadîslerdeki ilim meclislerinde, erkek meslektaşlarıyla birlikte, hadis eğitim-ögretim faaliyetlerini sürdürmüşlerdir. ${ }^{104}$

\section{Eser Telifi}

Hanım muhaddisler, daha çok, hadis ve kitap rivâyeti ile meşgul olmuşlar, eser telifi ile fazla ilgilenmemişlerdir. İçlerinde herhangi bir eseri olan çok az hanım vardır. Bu eserler de, onların adına talebeleri tarafından hazırlanan cüz ve meşyaha türü kitaplardır. Bilindiği gibi, muhaddislerin, "hocalarının rivâyeti olan hadisleri ve onların hocalarını ihtiva eden kitaplar hazırlama" âdeti vardır. Bazıı hadisç̧ler, hanım hocaları için de, bu şekilde eserler hazırlamıştır. Sonra, onlara okumak suretiyle, bu cüzlerin ve meşyahaların rivâyeti için, kendilerinden icâzet almışlardır. Kadınlar, daha çok, hadis kitaplarının âlî isnatlarını elde edip, onları talebelerine okutma ve icâzet verme işine önem vermişlerdir. Bu yüzden, eser müellifi olan yüzlerce muhaddis arasında, hanım isimlerine nadiren rastladığımızı özellikle belirtmek isteriz.

\section{Sonuç}

Kadınlar, sahâbe neslinden itibaren, Hz. Peygamber'in hadislerinin muhafazası ve neşri hususundla, erkeklerle birlikte önemli bir rol üstlenmişlerdir. Sahâbe ve tâbiîn nesillerinden, sayılanı azımsanmayacak ölçüde kadın râvî bulunmaktadır. Üstelik bunların bir kısmı, Tefsir, Hadis ve Fıkıh gibi dinî ilimlerde büyük âlimlırdir. Bu ilimlerle ilgili meselelerde, kendilerine müracaat edilmekte ve söyledikleri kabul edilmektedir.

Hicrî ilk asırda, sahâbe ve tâbiîn neslinden bir çok hanım, hadisleri rivâyet ederek, yazarak-yazdırarak, kendilerine sorulan hususlara cevap vererek, yanlış bilinen ve ‘ktarılan hususları düzelterek, Peygamber'in (a.s.) sünnetinin sonraki nesillere intikâlinde, erkeklerle birlikte üzerlerine düşen görevi yerine getirmeye çalışmışlardır. Onların büyük çoğunluğu, hadis rivâyetinde sika/guivenilir kişiler olarak kabul edilmektedir. Çok azı, kendilerinden sadece bir kişi rivâyet ettiği için, "kim olduğu bilinmiyor" şeklinde bir tenkide maruz kalmıştır.

Hicrî ikinci asın ortalarından itibaren, muhtelif şehirlerdeki âlimler tarafından, telif çalışmalarının yapıldığı bilinmektedir. Bu çalışmaların neticesinde, rivâyetlerin bijyük çoğunluğu kitaplarda toplanmıştır. Hadislerin tasnif ve değerlendirme çalışmalarının, üçüncü asrın sonuna kadar sürdüğü

\footnotetext{
${ }^{103}$ Fâtıma bint Muhammed (5:9/1144), Zeyneb bint Abdirrahmân (615/1218) ve Âişe bint Muhammed b. Abdilhâdî (816/1413) de, dönemlerinde. Buhârn'nin Sahîh'ini rivâyet ctmekle meşhurdurlar. İbn Nukta, s. 498, 501: Fâsî, Il, 381.

${ }^{104}$ Bazı örnekler için bkz. Fâsî . II, 359, 371, 380; Sıddîkî. s. 136.
} 
kabul edilir. Bu dönemde, hadis ile iştigâl eden kadın sayısı, bir hayli düşüktür ve içlerinde kitap telif eden kimse yoktur. Üçünciu asrın meşhur muhaddislerinin, hanım hocalardan çok az rivâyet etmiş olması, kanaatimizce buna bağlanabilir. Her nedense, kadınların, telif-tasnif döneminde, hadis çalışmalarına pek fazla katılmadıkları anlaşılmaktadır.

Dördüncü hicrî asırdan itibaren, hadislerin rivâyetiyle birlikte, hadis kitaplarının ve cüzlerinin rivâyet edilmeye başlaması, hanımların tekrar Hadis ilmine rağbet etmelerine sebep olmuştur. Bu rağbet, sonraki asırlarda artarak devam etmiş ve hadis ile iştigâl eden hanım sayısı yükselmiştir. Bu durum, onuncu asra kadar sürmüş, daha sonra sayı tekrar düşmeye başlamıştır. Günümüzde, hanımların Hadis ilmiyle ilgisi, bildiğimiz kadarıyla, daha çok akademik çalışma yapma şeklindedir. Sayıları da, her zaman olduğu gibi, erkeklere oranla oldukça azdır.

Bu makalemizde ulaştığımız başlıca sonuç; kadınların, özellikle hicrî beşinci-onuncu asırlar arasında, Hadis ilmine çok ilgi göstermiş olmaları hususudur. Onların bu dönemdeki hizmetlerini; "hadis ve hadise dair eserlerin rivâyeti", "talebe veya hoca olarak eğitim-öğretim faâliyetinde bulunma" ve "eser telifi" başlıkları altında incelemeye çalıştık. Bu dönemdeki hanım muhaddisler hakkında bazı değerlendirmelerde bulunmak istiyoruz.

Hanım muhaddislerin büyük çoğunluğu, Hadis ilmiyle meşhur olan âilelere mensuptur. Muhaddisler, eşlerini, kızlarını ve diğer kadın akrabalarını, bu ilme teşvik etmişlerdir. Seyahatlerinde, onları yanlarında götürerek, âlimlerin derslerini dinlemelerini ve onlardan icâzet almalarını sağlamışlardır. Hattâ, âlî isnada sahip olmalarını temin için, daha küçük çocuk iken, muhaddislerin derslerine götürerek, semâ yoluyla okunan kitabın rivâyet hakkını aldırmışlardır. Dolayısıyla, hanım muhaddisler bu yönlerden şanslı sayılabilirler.

Muhaddisler, kitaplara âlî isnatla sahip olmayı gerçekten çok isterler. Temyiz çağından önceki semâyı dikkate almadığını söyleyenler olsa da, çocukların küçük yaşlardan itibaren âlî isnat temini için, hadis derslerinde bulundurulması âdeti yaygındır. Küçük yaşlarda hadis kitaplarının okunduğu derslerde hazır bulunan kız çocuklarının isimleri semâ kayıtlarına geçer. Bunlardan uzun ömürlü olanlar, daha sonra, bu kitapları âlî isnatları ile rivâyet ettikleri için, muhaddisler onlardan semâ veya icâzet yoluyla o eserlerin rivâyet hakkını almaya çalışmışlardır.

Kadın muhaddislerin bir çoğunun uzun ömürlü olması dikkat çekicidir. Belki de muhaddisler, âlî isnada büyük önem verdikleri için, uzun ömürlü olan hanım hocalardan semâ etmeye veya icâzet almaya çalıştıkları için, kaynaklarda onların adları zikredilmiştir. Yaşlı insanların zihin fonksiyonlarında genellikle zayıflama görüldüğü bilinir. Ancak uzun ömürlü hanım muhaddislerden, bu duruma düştüğü bildirilenlerin sayısı, genele nispetle oldukça azdır. Muhaddisler, uzun ömürlü hanım hocalardan, semâ veya icâzet yoluyla, hadis kitaplarının rivâyet hakkını almak için, âdeta yarış etmekteler ve bununla övünmektedirler. 
Bu asırlarda, eğitim-ǫ̈̆retimde yaygın olarak icâzet yöntemi kullanılmaktadır. Kadın talebe ve hocalar için, bu yöntemin daha çok kullanılacağı açıktır. Muhaddisler, henüz çocuk yaşta veya tahsil çağında olan kızlarına, dönemin meşhur âlimlerinden icâzet alırlar. Aynı şekilde, meşhur muhaddislerin de, kendilerinden icâzet aldıklanı birçok hanım hocaları vardır. Derste hazır bulunup, okunan kitabın rivâyet hakkını semâ yoluyla almak, elbette daha üstün bir yöntemdir. Ancak bu, her zaman mümkün olmaz. O zaman, eserin rivâyet hakkına sahip olan muhaddis, talebelerine bu hakkı yazılı bir izinle devredebilir. İki tarafın da ehil olması şartıyla icâzet yöntemi, ilim alış-verişini kolaylaştırması açısından faydalıdır. Kanaatimizce muhaddisler, kitaplardan "rnuielliflerine ulaşan bir isnatla istifade etme"nin gerekliliğine inandıkları için, icâzet yöntemine çokça baş vurmak zorunda kalmışlardır.

Bugünkü eğitim-öğretim yöntemleri açısından baktığımızda, "henüz okunanı anlayacak yaşta olmayan çocukların hadis derslerine getirilmesi, ileri derecede yaşlı insanların hadis kitaplarını talebelerine rivâyet etmesi ve icâzet yönteminin geniş bir şekilde kullanılması" gibi hususların, bir çok yönden tenkide açık olduğunu söyleyebiliriz. Ama, bunların, birkaç asır boyunca hadisçiler tarafından kullanıldığı ve bir ölçüde ilmî canlılığı să̆ladığı da bir gerçektir. Öyle ki, arkadaş olan muhaddisler, memleketlerinde bulunan hadis hocalarından icâzet alarak, birbirlerine gönderme hususunda anlaşıyorlardı. Beldelerindeki muhaddislerle ilgili malumatı yazarak arkadaşlarına gönderme âdeti, hadisçiler arasında oldukça yaygındı. Böylece, özellikle biyografik malumat konusunda, muhaddisler arasında güçlü bir bilgi akışı sağlanmış oluyordu.

Kadınların, talebe veya hoca olarak, hadis eğitim-öğretimi faaliyetinde önemli bir rol üstlendiğini görmekteyiz. Bir müddet, değişik hocaların derslerini dinleyerek veya icâzet alarak, hadis tahsilini tamamladiktan sonra, sahip olduklanı birikimi ıalebelerine aktarmışlardır. Hadis ilminin değişik branşlarındaki birçok kitap; evlerde, câmilerde, ribâtlarda yapılan derslerde, hanım muhaddisler tarafından okunmuş ve okutulmuştur. Önemli hadis kitaplarını rivâyet eden onlarca hanım muhaddis vardır. Birçok meşhur muhaddis, derslerine devam ederek, onlardan bu eserlerin rivâyet hakkını almıştır. Hadisçilerin, talebe veya hoca olarak birbirlerinden karşılıklı istifade etmeleri, ömür boyu sürer. Zira herkes, sahip olduğu bilgiyi başkasına aktarır.

Kadınların, hadis kitaplarının sonraki nesillere asıllarına uygun şekilde nakledilmesinde büyük hizmetleri olmuştur. Hocalarından semâ veya icâzet yoluyla devraldıkları sigglam nüshaları, yine aynı yollarla talebelerine aktarmışlardır. Böylece hanım muhaddisler, kültür mirasımızın naklinde önemli bir görev îfâ etmiş olmaktadırlar. Ancak onlar, eser telifi işiyle fazla ilgilenmemişlerdir. Sadece, bir çoğu talebeleri tarafından derlenmiş olan, sahip oldukları rivâyetlerin ve hocalarının söz konusu edildiği cüz ve mu'cem-meşyaha türü ça!!ı̧̧maları vardır. 
Netice olarak, kadınların Hadis ilmine yaptıkları en büyük katkının; "ilk üç asırda hadisleri, sonraki asırlarda ise hadise dair eserleri rivâyet etmek, bunun için talebelerine hadis okutup icâzet vermek" şeklinde olduğunu söylememiz, doğru bir tespit olacaktır. 


\section{Ek: Kadın muhaddislerin ciiz, mu'cem- meşyaha türü eserleri}

Bîbâ (Bîbî) bint Abdissamed (477/1084), İbn Ebi Şüreyh (Abdurrahmân b. Ahmed)'in rivâyıtetlerini ihtiva eden cüzü ondan rivâyet etmiştir. Daha sonra bu cüz, Cüz'ü Bî̀bâ(Bîbî) diye meşhur olmuştur. Çünkü birçok muhaddis, onu Bîbâ'dan rivâyet etmektedir. ${ }^{105}$ Ebû Abdillah İbn Bâkûye, Ebû Ali ed-Dekkâk' ın kızı Fâtıma için bir Fevâid tahriç etmiştir. ${ }^{106}$ "İbnü'lAhdar" diye bilinen Abdülazîz b. Mahmûd, Şühde bint Ahmed (574/1178)'in hocaları için bir Meşya hazırlamıştır. ${ }^{107}$ Meşhur muhaddis Silefî (576) 1180)'nin, içlerinde Lâmi`a bint Sa 'î́d'in de bulunduğu bir grup hocasından naklettiği rivâyetleri ihtiva eden bir cüzü vardır. Bu cüz, bazen Cüz'ü Lâmi' $a$ ve Men Meahâ şeklinde zikredilir. ${ }^{108}$

İsbehân'ın müsnidesi, Afîfe bint Ahmed el-Fârkâniyye (606/1209)' nin Meşyaha'sı vardır ${ }^{K / 9}$ Münzirî, hocası Ebü'l-Hasen el-Makdisî'nin (611/1214) kız kardeşi Hatîce (618/1221) için, ona icâzet veren bir grup hocasının rivâyetlerden oluşan bir cüz hazırlamış, sonra bu cüzü kendisinden semâ etmek suretiyle rivâyet etmiştir. ${ }^{110}$ Şam'ın müsnidesi, uzun ömürlü, talebeye rivâyetten hiç usianmayan Kerîme bint Abdivehhâb (641/1243)'In âlî isnatlı hadislerinin toplandı̆̆ı 'Avâlî'si vardır. Zekiyyüddîn el-Birzâlî̀'nin onun için hazırladığı sekiz cüzlük Messyaha'sını Zehebî semâ etmiştir." Âlî isnat bakımından zamanının tek kişisi olan Bağdat'lı 'Acîbe bint Ebî Bekr Muhammed (647/1249) için on cüzlük bir Meşyaha hazırlanmıştır. ${ }^{112}$ Ebû Bekr b. Eyyûb'un kızı Mü'nise Hatun (693/1294)'un hocalarından icâzet yoluyla rivâyet ettiği hadislerden, senetlerinde yedi ve sekiz râvî bulunanları, Ebü'l-Abbâs Ahmed b. Muhammed b. ez-Zâhinî tahriç etmiştir. Mü'nise Hatun, bu kitabı h. 692 yılının Ramazan ayında Kâhire'de Zümrüd sarayındaki evinde rivâyet etmiştir. ${ }^{113}$

Takıyyüddîn İbn 'Arrâm (Muhammed b. Ahmed), hanım muhaddislerden Vecîhe bint Ali el-Iskenderâniyye'nin (732/1332) hocaları için bir Meşyaha hazırlamıştır. İ̉n 'Arrâm'dan önce, İbn Râfi' de, bu Vecîhe için bir Meşyaha yazmıştır. ${ }^{114}$ Zeyneb bint Yahyâ (735/1334)'nın Meşyaha'sı

105 Zehebî, Nübelâ, XVIII, 403-404; İbn Hacer, Müessis, I, 119, 272; II, 152. Bu cüz, Kuveyt'te 1406 'da basılmıştır.

${ }^{106}$ Sañfinîi, s. 459.

${ }^{107}$ İbn Hacer, Müessis, I, 144; Kettânî, Fihris, II, 655. Zehebî, bunu semâ ctmiştir. Nübelâ, $\mathrm{XX}, 542$.

${ }_{108}$ Ibn Hacer, Müessis, II, 20.

(1*) Ibn Hacer, Müessis, I, 347. 'Afife için bkz. Zehebî, Nübelâ, XXI, 481-483.

${ }^{1110}$ Meşhûr b. Hasen, s. 40.

I'" Zehebî, Nübelâ, XXIII, 92-93; libn Hacer, Müessis, II, 418.

${ }^{112}$ Zehebî, Nübelâ, XXIII, 232-233; Kettânî, Fihris, II, 653.

${ }^{113}$ Fâsî, II, 395. Ibn Hacer, Sümâniyyât Mü'nise Hâtûn ve Mâ Meahâ adiyla zikreder.

Müessis, Il, 495, 553.

$1 / 4$ İbn Hacer, Müessis, II, 492, 639; Kettânî, Fihris, II, 654. 
vardır. ${ }^{115}$ Âişe bint Muhammed el-Harrâniyye (736/1335)'nin Meşyaha'sı vardır. ${ }^{16}$ Alemüddîn el-Birzâlî (el-Kâsım b. Muhammed), hocası Zeyneb bint el-Kemâl (740/1339)'in rivâyetlerinden muvâfakât şeklindeki isnatlarla nakledilenleri tahriç etmiştir. Bu çalışma, Muvâfakâtü Zeyneb bint el-Kemâl şeklinde meşhur olup, rivâyet edilmiştir. ${ }^{177}$ Muhammed b. Yahyâ ise, iki büyük cüz hacminde bu Zeyneb'in Meşyaha'sını hazırlamıştır. ${ }^{118}$ Fâtıma bint el-`Izz İbrâhîm (747/1346)'in bir talebesi tarafından hazırlanan Meşyaha'sı vardır. ${ }^{119}$ Zeynep bint İsmâil'in $(750 / 1349)$ de bir Meşyaha'sı vardır. ${ }^{120} \mathrm{er}$ Reşîd el-'Attâr (Yahyâ b. Ali), Emetullah (Meryem) bint Ebi'l-Kâsım Abdirrahmân (758/1357)'ın hocalarından icâzet yoluyla rivâyet ettiği hadisleri bir cüzde toplamıştır. Bu cüz, Meşyahatü Emetullah ismiyle de zikredilir. ${ }^{121}$

Halîl b. Muhammed, Sittü'l-Kudât bint Abdilvehhâb (801/1398)'ın hocalarından rivâyet ettiği hadislerden kırk hadis ve Sittü'l-Küll bint ez-Zeyn Ahmed (803/1400)'in hadislerinden bir cüz oluşturmuştur. ${ }^{122}$ İbn Hacer, hocalarından Meryem bint Ahmed (805/1402)'in hocaları ve onlardan naklettiği rivâyetler için bir $M u^{\prime} \mathrm{cem}$ telif etmiştir. O, el-Meşyahatü'l-Bâsime li'l-Kıbâbî ve Fâtıma adlı eserinde ise, hocalarından Abdurrahmân b. Ömer el-Kıbâbî (838/1434 ) ile Fâtıma bint Halîl'in (838/1434) hocalarını ve onlardan aldıkları rivâyetleri işlemiştir. ${ }^{123}$ Seyyide bint Mûsâ elMârâniyye'nin iki cüzlük bir Meşyaha'sı vardır. ${ }^{124}$ Esmâ bint Ahmed'in bazı hocalarından naklettiği rivâyetler bir araya toplanmıştır. ${ }^{125}$ Âişe bint Muhammed b. Abdilhâdî (816/1413)'nin Meşyaha'sı vardır. ${ }^{126}$ Halîl b. Ahmed, Sittü'l-Ehl (Hasene) bint et-Taberî'nin hocaları için bir Meşyaha

\footnotetext{
115 Ibn Hacer, Müessis, I, 493; Kettânî, Fihris, II, 654.

${ }^{116}$ İbn Hacer, Müessis, II, 347; Kettânî, Fihris, II, 654.

117 İbn Hacer, Müessis, I, 237, 566, 588; II, 232, 270, 322, 347, 544. Bu cüzün, Ehâdîsü Muvâfakât 'Avâlî Binti'l-Kemâl adıyla yazma nüshası için bkz. el-Fihrisü'ş-Şâmil li'tTürâsi'l-Arabî ve'l-Islâmî 'Amman, 1411/1991' I, 48.

${ }^{118}$ İbn Hacer, Müessis, II, 347.

${ }^{119}$ Ibn Hacer, Müessis, II, 503; Kettânî, Fihris, II, 654.

${ }^{120)}$ Kettânî, Fihris, II, 654.

121 Ibn Hacer, Müessis, II, 71; Kettânî, Fihris, II, 653. Yirmi dört rivâyeti ihtiva eden cüz, Mecdî es-Seyyid'in tahkiki ile, Müsnedü Emetillâh Meryem bint Abdirrahmân elHanbeliyye adıyla basılmıştır. (Kâhire, 1409)

${ }^{122}$ Ibn Hacer, Müessis, I, 616, 617.

${ }^{123}$ Abdülmün'ım, I, 494-497. Hem Kıbâbî hem de Fâtıma'nın hocası olanlanın sayısı 52, sadece Kıbâbî'nin hocası olanların sayısı 84, sadece Fâtıma'nın hocası olanların sayısı ise 30 'dur.

${ }^{124}$ İbn Hacer, Müessis, II, 210; Kettânî, Fihris, II, 653.

${ }^{125}$ İbn Hacer, Müessis, II, 420.

${ }^{126}$ Kettânî, Fihris, II, 653.
} 
hazırlamıştır. ${ }^{127}$ en-Necm İon Fehd, Zeynep bint Abdillâh (861/1457)'ın hocaları için el-Fevâidü'l-Hâşimiyye adında bir Meşyaha derlemiş, Zeynep bunu ve başka kitapları rivâyet etmiştir. ${ }^{128}$ Esmâ bint el-Mihrânî (867/1462)'nin hocaları için iki âlim Meşyaha hazırlamıştır: el-Kutb elHaydarî ve Ibnü'l-Lebûdî. Haydanî, bu Meşyaha'da onun on sekiz hocasından naklettiği otuz hadisi toplamıştır. İbnü'l-Lebûdî, Meşyaha'sını bitirmeden bu hanım vefat etmiştir. ${ }^{129}$

${ }^{27}$ Kettânî, Fihris, Il, 655.

${ }^{128}$ Sehâvî, ed-Davü't-Lâmi', XII, 43, nr. 251; Kettânî, Fihris, II, 653.

${ }^{12 x}$ Sehâvî, ed-Dav'ü'l-Lâmi', XII, 6; Kettânî, Fihris, II, 652-653. Bu Esmâ bint el-Mihrânî'nin (el-Hemdânî?) Sebet'i vardır. Kutbuddîn el-Haydarî (Muhammed b. Muhammed), ondan otuz hadis seçerek bir cü:: oluşturmuştur. Bu çalışmanın, Cüz' fihi selâsûne hadîsen muvâfakât ve ebdâl ve 'avéli min Sebeti Esmâ bint el-Hemdânî adıyla yazma nüshasının bulunduğu bildirilmektedir. ¿əl-Fihrisü's-sâmil, I, 468, 629. 